\title{
Peertechz
}

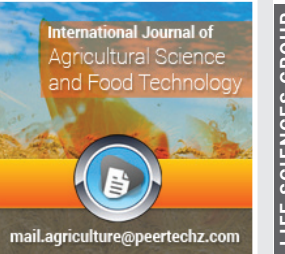

\section{Enset (Ensete Ventricosoum) Value Chain in Dawuro Zone, Southern Ethiopia}

\author{
Ashenafi Haile ${ }^{1}$, Berhanu Megerssa ${ }^{2 \star}$ and Rijalu Negash ${ }^{3}$ \\ 'School of Plant and Horticultural Science, Hawassa University, P. O. Box 05, Hawassa, \\ Ethiopia \\ ${ }^{2}$ College of Agriculture and Veterinary Medicine, P.O.Box, 307, Jimma, Ethiopia \\ ${ }^{3}$ Assistant professor, Agricultural Economics and Agribusiness Management, Jimma \\ University, Ethiopia
}

Received: 18 June, 2020

Accepted: 24 August, 2020

Published: 27 August, 2020

*Corresponding author: Berhanu Megerssa, Assistant Professor, College of Agriculture and Veterinary Medicine, P.O.Box, 307, Jimma, Ethiopia, Tel: +251931995050; E-mail: berhanu.beraka@ju.edu.et, berhanu.megerssa@gmail.com

Keywords: Actors; Enset; MVP; Value chain; Tobit https://www.peertechz.com

\section{Check for updates}

\section{Abstract}

This study was conducted in Dawuro zone southern part of Ethiopia with aim of analyzing enset value chain with specific objectives of identifying actors and their functions along the value chain, examine the share of benefits along 'enset' value chain, analyze factor affecting market participation and outlet choice of producer. The multi-stage sampling method was employed to select representative producers. The data were collected from both primary and secondary sources. Primary data was collected from 152 producers' 57 traders and 66 consumers, respectively. While secondary data were collected from published and unpublished documents. Descriptive statistics, econometric models of Tobit regression and multivariate probit methods were used to analyze the data using STATA software. Participation and level of market participation were used as a dependent variable to analyze determinants of enset market participation. Market outlet choice was used as a dependent variable to investigate factor affecting outlet choice of the producer. The finding of the study revealed that major actors of the value chain are, input suppliers, enablers, enset producers, local collectors, wholesalers, retailers, and consumers. The performance of actors in value chain emphasized that about $26 \%$ kocho and $25.95 \%$ 'bulla' profit margin shared by producers. Similarly, local collectors, wholesaler, and retailers have shared $27 \%, 22 \%$ and $25.08 \%$ of kocho; and $25.32 \%$, $22.15 \%$ and $26.5 \%$ share of bulla margin respectively. Retailers got a high share of profit $26.5 \%$ from bulla. Moreover, local collectors get $27 \%$ share of profit from 'kocho'. However, farmers have the lowest share of profit margin (26\%) since local collectors and wholesalers govern the chain. the econometric result revealed that distance to nearest market at $10 \%$, family size $10 \%$ and incidence of the disease at $5 \%$ determined the probability of farmer's market participation negatively and significantly. Education level $1 \%$, quantity produced at $1 \%$, consumer preference at $1 \%$, transport facility at $1 \%$ and Price at $1 \%$ is determining the market participation of the producer positively and significantly. The result of multivariate probit model indicated that the outlet choices have significantly influenced by age of producer, education level, and distances to market, extension contact, packing animal owner, labor availability, output produced and price of the products. Moreover, the model result indicated that the predicted probability of choosing direct-consumers outlet was (29\%) which is relatively lower than collectors (44\%) retailers (38\%) and wholesaler outlets (69\%), since they face constraints immediately to get direct consumers, the probabilities of producers jointly to choose and not to choose four outlets were $2.29 \%$ and $5.43 \%$ respectively. The Wald $\chi 2$ test value of 112.64 , which is significant at $1 \%$ significance level indicating that separate estimation of choice of four outlets is biased, and the decisions to choose the four outlets are interdependent and simultaneous. Therefore, collective efforts required motivation of extension agents and linking actors with the market are recommended to increase value chain of enset product in the study area.

\section{Introduction}

\section{Background and justification}

Ethiopia has diverse agro-ecological and climatic conditions suitable for production of various crops including root and tuber crops which play vital roles in food security of the people for over 20 percent of the population living in South and Southwestern parts of the country. Root and tuber crops are significant contribution to food security, income generation ,source of food ,provision of food energy and resource base conservation [1,2] Among these enset(ensete ventricousoum) is one of the native food security root and tuber crop in Ethiopia ;and ones it has also along been served as an emergency food crop in Vietnam during the second world war [3]. Enset growing farmers in Ethiopia described its importance by saying "it is everything for us; our food, cloth, house, cattle feed and plates. 
The major products obtained from 'enset' are 'amicho ' 'kocho', and ' bulla'. 'Kocho'is the main product of 'enset' crop consumed after being baked in a form of a pancake, and 'bulla' is a solidified residual by-product obtained in the process of producing 'Kocho', and it is the most expensive of all the products of 'Enset', and traditional food item served on holidays and different cultural occasions [4].

Enset grows at a wide range of altitudes, but, it grows luxuriously at an elevation between 2000 and 3000 m.a.s.l under rain fed conditions [5]. In Ethiopia more than 3 million hectares of land is covered by enset and about 0.69 million tons of enset yield is produced annually [6]. The crop is being grown in many regions, but the dwellers of the central and southwestern parts of Ethiopia are the only people who usually used its products as a staple and co-staple food [7]. Thus, south and southwestern parts of Ethiopia have a long history of cultivating and using of root and tuber crops as a staple diet [4].

Kocho, bulla and amicho are the major products obtained from enset in order of significance. Kocho is consumed after being baked in form of a pancake, whereas bulla, which is a solidified residual by-product of enset, is obtained in the process of producing Kocho. The former is the most expensive of all products; and it is mostly served on holidays and cultural occasions $[4,8]$.

Enset is also a source of starch for domestic and industrial uses like making of paper, adhesives and some verities of enset are used for local medicationon bone fracture, diarrhea, discharging placenta, forhumans and animals[4].

Enset penetrating from rural to center and northern part of Ethiopia by creating income opportunity every actor participating in value chain activity and add value to the product at stages of value chain to gain high income and bring with different benefit at the marketing activity for each and individual actor till to reach the end consumer [9].

The lowest participation of producer to enset market and fewer abilities to good outlet choice generate limitation to output to distant, but rewarding markets due to high transaction cost arising from transportation and the high opportunity cost of labor involved. Therefore, improving the position of producing farmers to actively participating in the market and outlet choice was the most important issue. However, Producers and consumers separated by settlement order, and most farmers have found in the rural areas; consumers and hotel owners market which gave a good price was found at urban market outlets.

Enset is the major food item for rural and urban areas of Dawuro zone to which the increasing population pressure is major barrier affecting different crop production in study area [10]. Similarly, the food potential of enset has not fully been exploited and utilized compared to cereals [2]. Mareka and Loma Woreda are located in this locality in to which enset has significant contribution both as a source of food generation of income for the people in the area. Therefore, this study is focused in finding out of the value chain analysis of enset in the study area.

\section{Statement of the problem}

Poor marketing and institutional services like lack of credit, transport facility and limited extension services has affected producer's market participation and outlet choices for cereal crop products. But these effects accompanied by social institutional demographic and infrastructural challenges were not well studied for enset at study area.

Despite, enset importance in improving welfare of farmers through household income, food security, poverty reduction and promotion of nutritional status, its actors' role and is not well distinguished. Likewise, a share of benefit along the chain is not well identified in Mareka and Loma Woreda. Similarly, consumers' preference for enset is increasing in urban areas of the study area. Due to institutional and socio-economic factors affecting producers, the participation of farmers to urban consumer's and hotel owner are threatened.

In addition, there is less institutional support for producer and limited organization among enset value chain actors performing different activities from design of enset to production, decorticating, transporting and marketing. However, there is limited research conducted to address existing challenges in the study area. Thus, this study aimed to examine the entire value chain of enset filling the gaps along enset value chain

\section{Research question}

- Who are the actors involved in the enset value chain?

- What is the share of benefits distributed along enset value-chain actors?

- What are the factors affecting producers market participation?

- What are factors affecting the enset market out-let choice of the producer?

\section{Objective of the study}

General objective: The general objective of this study is to analyze the value chain of 'enset' at Mareka and Loma Woredas of Dawuro zone.

Specific objective: The study specifically tries to:

$>$ To identify actors and their functions along enset value chain in the study area.

$>$ To examine shares of benefit along enset value chain actors.

$>\quad$ To analyze factors affecting the market participation of producer.

$>$ To investigate factors affecting market outlet choice of producers.

Citation: Haile A, Megerssa B, Negash R (2020) Enset (Ensete Ventricosoum) Value Chain in Dawuro Zone, Southern Ethiopia. Int J Agric Sc Food Technol 6(2): 126 


\section{Research methodology}

\section{Description of study area}

The study was conducted at Mareka and Loma Woredas of Dawuro Zone. The livelihoods of the Woredas are based on subsistence farming which typically are of mixed type of farming including (enset, maize, teff, cotton, peas, beans spices) and animal husbandry. The soil type of the study areas is well-drained and weathered reddish-brown soil (Nitsoils and Orthic Acrisoils) [11] which are good for enset crop production.

The total population of Mareka Woreda is 145,955 of which $(49.2 \%)$ are males and the remaining are (50.8\%) females. Simultaneously (91.9\%) of in habitants reside in a rural area whereas $36 \%$ of them are Highlanders and the rest $51 \%$ and $13 \%$ are living in mid and lowland areas [1]. Among 34 rural kebeles and 3 urban kebeles, 16 are enset producers. The Woreda are geographically situated between $6^{\circ} 0^{\prime \prime}$ and $7^{\circ} 21^{\prime \prime}$ $N$ Latitude and $37^{\circ} 01 E^{\prime \prime}$ and $37^{\circ} 26 E^{\prime \prime}$ Longitude and their altitudes ranges from 1360-2541 m. above sea level and with a temperature range of $15-27.5$.The area covered by enset was 9000-hectare WoAOR (2019).

Loma is the neighboring Woreda to Mareka and it is bordered in North and North West by Gena- bossa in the Northeast by Wolaita zone and in the east-west by Gamo Gofa zones. The total area of the Woreda is $116,320 h a$, and the Agro ecology of the district comprises of $45.6 \%$ 'kola' (low land altitude less than 1500 meters above sea level $41.4 \%$ Weynadega (midland altitude, between 1500 to 2300m.a.s.l) and 13\% 'Dega'. The annual mean temperature of the Woreda ranges from15.1-29. $5^{\circ} \mathrm{C}$.The annual mean rainfall ranges from $900-1800 \mathrm{~mm}$. and Loma located between $6^{\circ} 56^{\prime} \mathrm{N}-7^{\circ} 36^{\prime} \mathrm{N}$ Latitude and $36^{\circ} 34^{\prime}$ $\mathrm{E}-37^{\circ} 64^{\prime} \mathrm{E}$ longitudes. According to the population census of CSA [5], the total population of Loma Woredas was about 109,192 (male 55,214 and female 53,978) and the districts comprise 34 rural kebeles and 5 urban kebeles out of this, 9 high land Keble's have high enset production potential [12]. The area covered by enset crop was 15000 -hectare WoAOR (2019) Figure 1.

\section{Sampling technique}

Farmers' sampling: Multistage-mixed sampling techniques were used to select sample respondents from the total population. At the first stage, simple random sampling is employed to select study Woredas. Where primarily districts were listed and categorizes in to their production pattern and level of income of farmers. Then, six kebeles were selected from high medium and low enset producing areas. Subsequently, determination of sample size is resolved by means of Cochran [13] sampling formula with as present interval level with 5 present desire level of precision with probabilities of 11 present.

$$
\mathrm{n}=\frac{\mathrm{z}^{2} \mathrm{pq}}{\mathrm{d}^{2}}
$$

Where $\mathrm{n}$ is the required sample size, $Z^{2} \cdot \mathrm{p}=$ is degree estimated proportion of an attribute of the study population

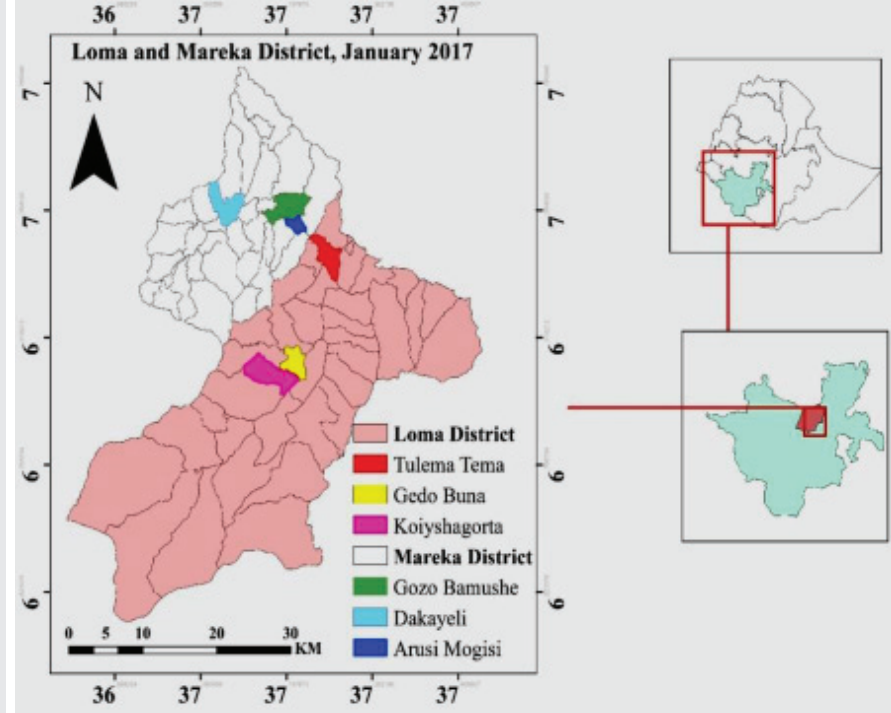

Figure 1: Map of the study area.

which is $11 \%$

$q=1-p$

Typical levels of confidence for this study were 95\% in which case $\mathrm{Z}$ is 1.96 .

$\mathrm{D}$ is the desired level of precision, which is 5 percent.

Hence, by employing probability proportion to size technique, 52, 50 and50 sample farmers were selected randomly representing: high, medium and low producing areas respectively making a total of 152 sample farmers .Afterwards, based on a sample collected from respective Keble administration systematic random sampling employed to depict the sample farmers .The numbers of farmers have been taken from each kebeles administrations.

$$
\text { Samplesize }: \mathrm{N}_{0}=\frac{1.96^{2} * 0.11 * 0.9}{0.05^{2}}=152
$$

\section{Trader sampling}

The trader surveys was conducted on Marka and Loma Woredas towns near to hotel centers in which 'enset' product like Kocho and bulla traders exist. Therefore, 57 traders were purposively selected based on their market participation and amount of capital invested in 'enset' product marketing.

\section{Consumer sampling}

Two types of consumers namely households and hotel owners were purposively selected. Hence 21 hotel owners and 45 household respondents were included in the survey from Mareka and Loma Woredas, respectively.

\section{Focus group discussion}

Four focus group discussions were made with model farmers, Kebeles representatives, traders and DAs to draw 
points of interventions and to assess internal weakness and strength of actors along the value chain.

\section{Method of data collection}

For data collection, well-developed semi-structured interview questions were prepared and first to preceding the survey, adequate training on the questionnaire and ways of the data collecting have been made by researcher himself and 12 sample questionnaires done by the researcher with the enumerators.

\section{Source of data}

The primary data were collected using three independent interview schedules, one for producers, the other for traders and the third for consumers. Secondary data was used from sources like reports of agriculture office, published and unpublished materials, marketing and cooperative office report, trade and industry office report and trade and industry departments.

The primary data were collected to know about demographics, socio-economic and institutional factors of the farmers in the study area. In addition, factors affecting farmer participation to market, outlet choice, to whom farmers are selling their product, the cost incurred from production up to marketing, the benefit in relation to quantity produced per hectare per year, the flow of information, service he gets and service providers data have been collected.

Traders demographic, socioeconomic data experience of trading, the flow of product from whom he buys and to whom he sales the product, the outlet he buys the product, in relation to flow of information and service he gets, the service providers for trader's data were asked. Thirdly, the cost he incurred and benefit of the trader at different channel and function of the individual trader on value addition of the product would answer.

Finally, the buying trend and preference of the product from which actor they buy the products were answered. Moreover, the income of the consumer, amount of the product they buy, and type of the product bought per week per month as data was collected.

\section{Type of data}

To conduct this study, both qualitative and quantitative type data were used like income from another source, age of farmer, and yield of enset, amount supplied to market, amount consumed and distance to market data were collected.

\section{Method of data analysis}

To this study, both descriptive and econometric analysis was used to conduct value chain analysis.

Descriptive statistics: To describe the characteristics of value chain actors' descriptive statistics like mean, standard deviation and percentage were used. To this effect, data are coded and entered into STATA version 13 accordingly. Inferential statistics such as hypothesis testing, $\mathrm{Chi}^{2}$, t-test, pseudo $\mathbf{R}^{2}$ and p-value used to test dummy categorical, continuous, and likelihood respectively.

Value chain analysis: Value chain analysis has adopted a framework for understanding key activities, relationships, and mechanisms that allow processors, buyers, sellers, and services they pass from one link to the other [14].

Mapping core processes in value chain, mapping main actors involved in these processes, mapping flows of products, information and knowledge, mapping volume of products, numbers of actors and jobs, mapping geographical flow of the product or service, relationships and linkages between value chain actors, the business services, that feed into the value chain have done.

\section{Analyzing marketing margin}

Estimates of the marketing margins are the best tools to analyze the performance of actors found in the market either selling or buying the commodity. Marketing margin is used to calculate the share of a particular actor in the value chain. For calculating the marketing margin of a particular actor, the average price of the product has taken. Computing the Total Gross Marketing Margin (TGMM) was related to the final price paid by the end buyer and is expressed as a percentage Mendoza [15].

There are traders at different marketing channel. Thus, the margin was calculated to find the price variation at different segments, comparing them with final price or the consumer's price and hotel owner has done. Hence, the consumer or hotel owner's price is the common denominator for all markets margins at different marketing outlets.

$$
T G M M=\frac{\text { last } \text { buyer price }- \text { farmer selling }}{\text { last } \text { buyer price }} \times 100
$$

TGMM: is total gross marketing margin.

$$
\text { GMMp } \frac{\text { End buyer price }- \text { gross marketing margin }}{\text { last buyer }} \times 100
$$

It is useful to show the farmer'participation share

Where, GMMp = the producer's share in consumer price (Last buyers are consumer's or hotel owner's)

Then, marketing margin at a given marketing outlet 'yi' (GMMi) was calculated as:

$$
G M M i=\frac{S P y i-P P y i}{T G M M} X 100
$$

Therefore, SPyi is selling price at $w i^{\text {th }}$ out let and PPyi is purchase price at $w i^{\text {th }}$ Outlet

Marketing margin varies due to value-added cost in marketing system.

Total gross profit margin also computed as: 


\section{TGPM=TGMM-TOE}

where TGPM is total gross profit margin, TGMM is total gross marketing margin and TOE is total operating expense. The study result by [16] showed that, profit margin by subtracting operating expense from marketing margin.

Quantitative data on the cost and revenue structures, value-added, benefit distribution were analyzed and computed using the terminologies briefly described by Marshall, et al. (2006). Profit margin at each stage was computed to evaluate the benefits along enset value chain, as:

Profit margin $=$ Revenue - Total cost

Where Revenue=Sales volume $*$ Unit price

\section{Econometric analysis}

Tobit regression model: Most of the population in study area participated in enset production both for food income source. But, the degree of participation varies among households based on production and marketing of enset. Analysis of factor affecting market participation and intensity was important to identify determinants of market participation. To determine the farmer's actual sales would have simultaneously affected by the variable.

Tobit model was used to interpret the perspective of the study to look factors that affect the market supply and intensity level of farmer's participation in the market. In case all farmers participate (OLS), model has applied, but in the preliminary reflection of the study, not all farmers are participating in enset supply to market. Therefore, the OLS regression was used to exclude the non-participants from the study; a sample selectivity biases have introduced into the model.

The observed amount of enset product output $\mathrm{Yi}^{*}$ that is actually sold in the market was used as a relevant proxy for intensity of market participation. The attention on the level of participation would enable to identify factors influencing household market participation. Sindi [17] jointly determined the quantity supply and level of participation in enset market. The models assume a normal distribution with constant variance Greene [18] and have specified as shown in the formula below:

$$
\begin{aligned}
& y i=x_{i}{ }^{\prime} \beta+\stackrel{\circ}{\boldsymbol{a}}_{\boldsymbol{i}}, \stackrel{\circ}{\boldsymbol{a}} \boldsymbol{y} \sim \boldsymbol{N}\left(0, \boldsymbol{o}^{2}\right) \\
& y i=0 \text { if } y i^{*} \leq 0
\end{aligned}
$$

$y i=$ Amount of enset supplied to market:which is a continuous variable between farmer's market participation 0 and 1.

\section{$x_{i}=$ Explanatory variables affecting the dependent variable}

$\beta=$ Vector of factor explained value of dependent variables market participation andlevel of participation

$$
\stackrel{\circ}{\boldsymbol{a}}_{\boldsymbol{i}}=\text { Is error terms, which is assumed to be normally }
$$
distributed
Multivariate probit model: Degye and Mengestu (2015) data analysis multivariate probit model analyzed the outlet choice determinants factor. The use of multivariate probit model is to investigate farmers decisions between potential joint alternatives is a consolidated technique within the agricultural economics literature in the field of information and knowledge transfer Velandia, et al. [19]. In this class of models, the response is multivariate correlated and discrete. The model is a generalization of the probit model used to estimate several correlated binary outcomes jointly Vithala [20]. Since, across-market outlet choice is prevalent among producer, socio-economic and demographic characteristics have varied influences on marketing and in different types of outlets.

The study examines the factor-affecting choice of producer characteristics on different outlets. The analysis includes four different equations modeling the frequency in each outlet of the farmer choice. The occurrence of cross-marketing leads to the correlation between the errors of those four outlets. A separate analysis of four equations may not give an accurate result. In this multivariate analysis is the most suitable method of estimation. Here the response variable is binary variable and multivariate probit methods were have used to estimate the equations. Determinants of the market outlet choice were identified by using Multivariate Probit model, some recent empirical studies of market outlet choices assume that farmers consider a set of the possible outlet and choose the particular marketing outlet that maximizes expected utility.

The addition or selection of alternative outcome does not affect the odds among the remaining outcomes and the odds of choosing a particular market to depend on which other outcomes are possibly chosen. However, in the present study, more than one market outlet would have available in the study area and farmers are more likely to choose more than one market outlets in order to address their multiple needs. In this case, the dependent variables are dichotomous variable indicating whether sales have made through the relevant marketing chain or not.

The market outlet has categorized into four groups: selling to wholesaler, selling to local collector, selling to retailer and consumers. Each farmer can use one or more marketing outlets or several joints of different outlets that maximize the expected utilities and due to this, there was the same overlapping and many farmers can sale with more than one market outlets. With respect to the structure of the theoretical model and the dependent variables, a recursive multivariate probit model is as a generalization of the bivariate probit model Maddala [21].

The multivariate probit model takes in to account the potential interdependence in the market outlet choice and the possible correlation in the choice of alternative outlets. The probabilities of preparing any particular marketing outlet were estimated conditional on the choice of any other related outlets. The multivariate probit model assumes that each subject has distinct binary responses and a matrix of discrete and continuous variables (Tibet, 2007). 
The model specified us:

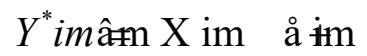

Where $Y^{*} \operatorname{im}(\mathrm{m}=1$ k) brepresent the unobserved latent variable of market out let's choose by $i^{\text {th }}$ farmers $(\mathrm{i}=1$

Therefore, in this case, $\mathrm{K}=$ wholesaler, collector, retailer, and consumer

Axim is one $\mathrm{x} \mathrm{k}$ vector of observed variable that affects the market outlet choice

The error term for each of the $M$ equations has standard normal distribution with mean zero and variance of one.

$\beta \mathrm{m}$ Is $\mathrm{a} \mathrm{k} \times 1$ vector of unknown parameters to be estimated, å imm $=1 \ldots \ldots \ldots . . . . M$ are the error terms distributed as multivariate normal. This system of equations is jointly estimated using maximum likelihood method. To have desirable properties in the context of multivariate normal limited dependent variables that, the simulated probabilities are unbiased, they are bounded within the $(0,1)$ interval and the simulator is a continuous and differentiable function of the model's parameters.

Y1=Wholesaler, 1 if collector, 0 otherwise

Y2=Collector, 1 if wholesaler, 0 otherwise

Y3=Retailer, 1 if retailer, 0 otherwise

$\mathrm{Y} 4=$ Consumer, 1 if consumer, 0 otherwise

$\mathrm{Y} 1=\mathrm{x} 1 \beta+\varepsilon 1 \quad(10)$

$\mathrm{Y} 2=\mathrm{x} 1 \beta+\varepsilon 2$

$\mathrm{Y} 3=\mathrm{x} 1 \beta+\varepsilon 3$

$\mathrm{Y} 4=\mathrm{x} 1 \beta+\varepsilon 4$

\section{Result and Discussion}

\section{Identification of actors and their function}

Market participation of Enset producer was influenced by many socio-economic and firm-specific characteristics.

\section{Farmers}

\section{Demographic factors}

Age: The mean age of producer's was 46.97 with a standard deviation of 10.91 and it was significant at $1 \%$ level. And age of head of household was not also significant among clusters of producers indicating that, farmers in study areas are younger and in productive age groups. This implied that, increase in age facilitated the wise use in resources, and it adds up on the increased experience to initiate for innovation; and then brought by better production and market participation. This result was in line to poision and spencer (1992) who reported that, younger households were more dynamic and eager to accept adoption and innovation and there by produced and sold more enset for market.

Sex of farmer: Among the household heads who participated in the survey $32.3 \%$ were female-headed while $67.7 \%$ were male-headed household indicating that, the role of women in enset production (Table 1). This result matches with Brandt, et al. (1997) said that Enset is a woman's crop where women's labor roles in the processing, cooking and selling of enset products.

\begin{tabular}{|c|c|c|c|}
\hline Variables & Mean & STD & $x^{2} \cdot$ test/t.test \\
\hline Age & 46.97 & 10.92 & $0.000 \star \star \star *$ \\
\hline Family size & 6.3 & 2.01 & $0.000 \star \star \star$ \\
\hline Sex (male) & 103 & $67 \%$ & 0.876 \\
\hline Education level & 1.59 & 0.75 & $000 * \star *$ \\
\hline Population pressure(yes) & 66 & 43.5 & 0.598 \\
\hline Landholding & 1.80 & 1.04 & $0.000 \star \star \star *$ \\
\hline Land allocated for enset & 0.599 & 0.3113 & 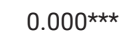 \\
\hline kocho quantity produced & 38.51 & 14.92 & 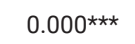 \\
\hline Frequency of harvest per month & 2.55 & 1.201 & 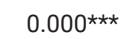 \\
\hline Bulla produced /year / $\mathrm{HH}$ in quintal's & 1.19 & 1.808 & $0.000 \star \star \star$ \\
\hline Consumer preference & 113 & $74.4 \%$ & $0.000 \star \star \star$ \\
\hline Labor available at hh in number & 3.15 & 0.982 & $0.0000 \star \star \star$ \\
\hline Access to market information(yes) & 60 & 39.5 & $0.001^{\star \star}$ \\
\hline Access to transport(yes) & 81 & 53 & 0.668 \\
\hline Access to credit(yes) & 67 & 44 & 0.502 \\
\hline $\begin{array}{l}\text { frequency of extension contacts at number per } \\
\text { month }\end{array}$ & 3. 86 & 1.824 & $0.000 * \star \star$ \\
\hline Distance to market(yes) & 8.07 & 7.04 & $0.000 \star \star \star$ \\
\hline Incidence of disease(yes) & 112 & 73.6 & $0.026^{\star *}$ \\
\hline Wild animals attack(yes) & 62 & $40.7 \%$ & 0.690 \\
\hline Pest(yes) & 59 & $38.8 \%$ & 0.136 \\
\hline
\end{tabular}

$\star \star \star, ~ * *$ and * employ $1 \%, 5 \%$ and $10 \%$ level of statistical significance Source: Own survey result (2019)

Education level of the farmer: The study result shows that mean of education 1.59 with a standard deviation of 0.75 . The lower mean result shows that more of farmers at study district were under illiteracy level have reduced their capacity of using and creating a new idea and getting of timely information. This result is a line to Takele [22]who reported, education enabled farmers' ability to do basic communications for business purpose.

Family size: The mean family size of respondents is about 6.3 with standard deviation of 2.015 and it was significant at $1 \%$. In addition, it is greater than both Regional and National family size 5.3 and 5.1 respectively CSA (2013). The result indicated that, larger availability of labor brought positive relation with volume of supply. Since, production is the function of labor

Citation: Haile A, Megerssa B, Negash R (2020) Enset (Ensete Ventricosoum) Value Chain in Dawuro Zone, Southern Ethiopia. Int J Agric Sc Food Technol 6(2): 126 
which positively affects farmer's decisions to participate in market and larger amounts of home consumption enhancing loss of wastage in case of marketability. This is in line with Musah [23] and [24] who reported enset production and marketing is labor intensive activity requiring families with more household members for better market outlet. Similarly, Wolday (1994) showed that, household size had significant positive effect on quantity of left marketed and impact on market participation and volume of sale. Congruently, the study result indicated that enset production and processing in the study area makes use of $60.5 \%, 17.8 \%$ and $15.1 \%$ of family labor, hired labor and community support through 'wonfel'/ 'debo', respectively, which is local 'dagwa' for digging the soil, tinning and wonder (Supriya) by females for processing products. In line with this Checka [25] has revealed that enset farmers use family labor to share the experience.

Population density: The increasing concern related to boosting population density is the first fact that was, largely damage production potential. This is due to a high number of family sizes, which fragment the land owned by the household for crop productions used for construction and urbanization. The study line with Teshome [26] stated that production potential of the situations has damaged by high population pressure for house construction and settlement apart from enset production.

Marital status: The result of discrete variable marital status shows that, from the sampled respondent $84.2 \%, 76.2 \%$ and $54 \%$ of producers, traders, and consumers respectively married.

\section{Socio-economic factors of farmers}

Landholding: The average land holding per household at study area was 1.80 hectare with a standard deviation of 1.04 and this was significant at $1 \%$ level. This size is very few in relation to national average households' land size 1.37 hectare (CSA, 2013). At the same token, 31\%of households allocated 0.59 hectares for enset production and this is greater than $17.5 \%, 25 \%, 15 \%$ and $11.5 \%$ for livestock, cereal, vegetable production and tree planting respectively. This largest share of land for enset had increased the marketable supply of and thereby encouraged farmers to participate in markets. This result is in line with Rehima (2005) who underlined that largest proportion of land allocation had increased marketable supply of peeper production and thereby direct increase of farmers' market participation.

Income source: $33 \%$ of respondents collected better off-farm income and thus their market participation was to limited. This result was in favor of [27] who confirmed nonparticipant households had higher off-farm income and thus they were reluctant to supply enset to market. This study line with Chandio, et al. [28] confirmed that non-farm income affected farmer's participation negatively in rural Georgia.

According to the study result trading, employment, labor, and handcraft are prior off-farm activities performed by farmers in that order respectively (Table 2) Figure 2.

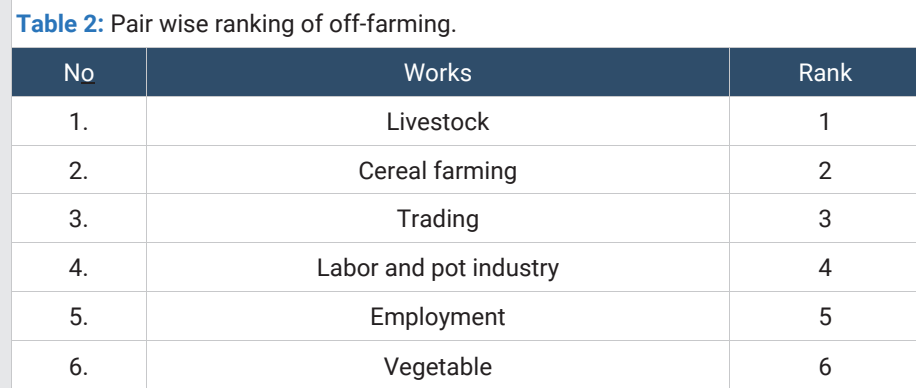

Source: Own survey result (2019)

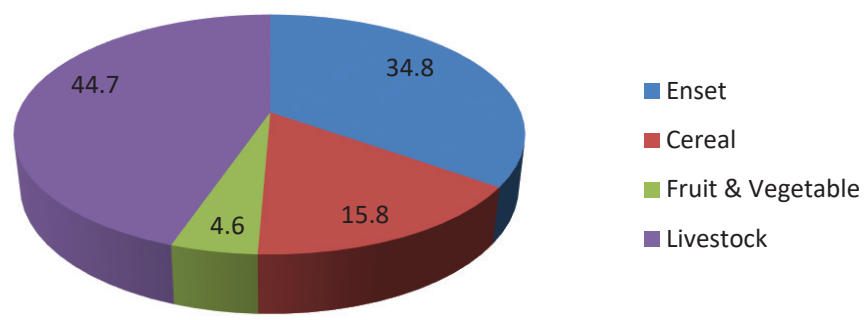

Figure 2: Source of income and food to study area.

Major Crops Produced in the study area: Livestock production accounts $44.7 \%$ source of livelihood for farmers in the study area followed by enset production which was the second major source of income $34.8 \%$ of the farming system followed by cereals $15.8 \%$ and fruit and vegetables $4.6 \%$.

Majority of the farmers in study area participate on market and added value through processing for the purpose of income generation and consumption. Respondents (37.5\%) replied that, they were processing enset crop for better price, to control the quality of the products $(27.6 \%)$ and to both fetch good price and control quality (34.9\%) are accounted. This study is in line with Geda (2009) [29] who said farmers are motivated to prefer enset and its products. Since it contributes to food security scheme and utilized for different purposes including the ability to produce more food than other cultural crops on a small piece of land with minimum inputs.

Quantity produced: the minimum and maximum numbers of enset trees harvested per year per household were 24 and 144 respectively. Accordingly, the average amount of enset products produced per year per household was 38.51 quintal which is relatively similar to the National average annual household production in surplus producing Woredas (35-70 quintal). This finding is also similar to the finding of Gebreselassie and Sharp [30] who reported households with a higher value of production sold their produce with better market participation.

Quantity Consumed: The result showed that $74.3 \%$ of respondents supplied enset to markets while; the remaining (25.7\%) of them consumed it at home. Hence, households who produced larger quantity Kocho have supplied their surplus products to markets indicating larger quantity of kocho produced can directly influence households' decision to participate in the enset marketing. Apart from the total annual enset production, $31 \%$ 'kocho' and $92 \%$ of bulla produce supplied to markets and this helped to increase market participation of producers. 
In addition, the remaining $69 \%$ of kocho and $8 \%$ of bulla consumed at home level reduced participation in the market at the season of the survey period.

Consumer's preference: From survey result, $74 \%$ of the respondents revealed that, positive feeling for enset. Since the plant is highly drought resistant, it provides fiber for making ropes mats, medicine that helps for wounds and breaks to heal faster and stronger and it provide water to the coffee seedling. In addition, the studies of [31] explained that there was high consumption of enset products in the study area and neighboring areas because of increasing cereals price and in relation to population growth and consumption demand.

\section{Institutional factor for actors}

Distance to market: The average distance of respondents to nearest market was $8.07 \mathrm{Km}$ and this distance to market increased for farmers transportation cost and there by reduced farmer participation to market. This result line with Nuri and Jema [32] who reported that the t-test result on market participation for nearer market distance is positive to enset products market participation. Similarly, Holloway, et al. (1999) reveled that milk market development in Ethiopia high lands indicated that distance to market caused milk market surpluses to decline.

Access to credit: $56 \%$ of the sampled farmer's did not have accesses of credit for purchase of inputs like: modern decorticating materials, medicines and packaging animals for transporting their produce. Hence in accessibility to credit decreased the financial capacity of farmers to purchase necessary inputs and negatively influenced market participation and volume of sale. The result is in line to [33] who emphasized that formal financial sector in Ethiopia have inadequate inclusion to rural areas and have high interest rate who repels users. Hence, access to credit facility has failed to incentivize farmers to produce more and supply better in market (Adugna, 2009).

Market information: The survey result indicated that $37.5 \%$ of produce accessed market information from relatives, friends and extension agents. This result agreed with [34] who found that majority of farmers rely on friends, relatives and agricultural extension agents for market information.

The frequency of extension contacts: Extension visit was directly lower when compared to other conventional in study area. This result was in line with Geda [29] who reported current extension approach was limited to conventional and this failed to bring major impacts on enset production where lack of extension service for enset has led to poor linkage to support enset commodity. This finding also in line with Carlson, et al. [35] explained, as the current extension approach was more in favor of cereals.

Means of transport: $47 \%$ of sampled respondents have no access to transport facility and thus, farmers were habituated using packing animals like Horse, Mules, Donkey, and family labor in that area. Therefore, the households with less or no family labor had exhibited low market participation and there by caused market surplus to decline. This result in line with Nwigwe [36] who underline transportation was a major marketing cost like Yam market participation and thus discharged from the urban market. Likewise, Eshetu [33] reported lack of transport problem was common challenge for producers Figure 3.

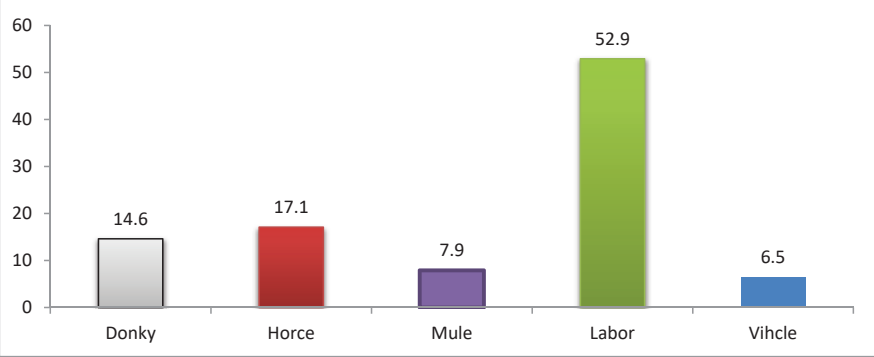

Figure 3: Means of transportation for enset product marketing (\%) Source: Own survey result (2019).

\section{Physiological factor for actors}

Disease incidence: The analysis showed $73.6 \%$ of the responded bacterial wilt disease incidence (locally known as ('Wolowa') was the major threat for market participation and critical problem affecting quality in the study sites. This result was similar to (Awol zeberg et al., 2014) who emphasized that bacterial wilt is the most economically important disease which is hampering enset farming in Ethiopia. In addition, the disease was a major constraint to enset production in Ethiopia, endangering the livelihoods of millions of farmers and threatening food security of over 15 million people for whom enset is a staple food [37].

Wild animal: Loss of enset product by wild animals like a wild pig (Suscrofa) locally known as` Gudunxa` and porcupine locally 'Quxaria' were most important threat requesting eminent attention for control. Hence, cultural and improved control mechanisms should be in place including: fencing, night lighting and making false man symbol keeping. The wild animals attacking a problem and controlling system were similar with (Bayani, et al. 2019). Assessment of crop damage by protected wild mammalian herbivores on the western boundary.

Pests: Mel bug is a common pest causing less standing of a plant, retarded growth and makes drying of sheaths, locally known as 'gorchwa'. The result is similar to the description of [38] who realized plant attacked by Mel bug dried tended to retarded growth and day at the end. The other common vertebrate pest responded from farmers was mole rat locally named as 'Ochuwa' which eat the corm part. This is in line with [39] who reported that, enset production and productivity is reduced by vertebrates such as Mole rate and porcupine Table 3 
Table 3: Factor affecting market participation of trader.

\begin{tabular}{|c|c|c|c|c|}
\hline Variables & Category & Mean(N) & STD (\%) & X2 /t-test \\
\hline Age & & 34.33 & 6.02 & $0.000^{\star \star \star}$ \\
\hline Family size & & 3.70 & 2.25 & $0.000^{\star \star \star}$ \\
\hline Sex & FHH & 57 & 100 & Constant \\
\hline Marital status & Married & 45 & 78.2 & 0.360 \\
\hline Education & Illiterate & 22 & 38.6 & 0.364 \\
\hline Religion & Orthodox & 19 & 33.3 & \\
\hline & Muslim & - & - & \\
\hline Year of experience & Protestant & 38 & 66.7 & \\
\hline \multirow{2}{*}{ Source of capital } & Catholic & - & - & \\
\hline & Family & 4.35 & 2.12 & $0.000 \star \star \star$ \\
\hline & Gift & & 66.7 & \\
\hline Initial capital & Own source & & 21.1 & \multirow{2}{*}{$0.002 \star \star$} \\
\hline Current capital & & 1034.24 & 1067.2 & $0.000^{\star \star \star *}$ \\
\hline
\end{tabular}

Source: Own survey result (2019)

Age: The mean age of sampled traders and consumer was 34.33 and 35.73 years of with standard deviations of 6.02 and 9.42 respectively and where both were significant at $1 \%$ level. This indicate that respondents where in younger age circle making them lean for innovation and market information.

Sex: As a survey, results indicated $100 \%$ of traders were females indicating that women played absolute role in bulla and Koch marketing in the study area.

Education level: The result realized that the education level of traders was poor since, $66.7 \%$ of traders were formally attended from grade lower primary school (grade 1-4) and the rest were illiterate. The result implied that traders had less know- how of modern marketing of Bulla and Kocho products based on customer preference and their technology adoption was so poor.

Family size: The mean family sizes were 3.7 and 4.62 with standard deviation of 2.25 and 2.02 respectively for traders and consumers. The result implied that excess number of family size for trader help to collect more products and to transport by family labor. Similarly, households with great family size were need food item like enset product with is less costly than cereal crop. The results in line with [31] reported that, increasing enset consumption because of increasing cereals price, population growth.

\section{Socioeconomic of traders and consumers}

Source of capital for trading: More of traders $66.7 \%$ have been using capital from family and followed by a gift from respective husbands (21.1\%), and loan from Omo Microfinance at the interest rate of $8 \%$. Others use own $3.1 \%$ capital sources and $8.8 \%$ uses from traditional saving (Iqub).

Income source of the consumer: According to consumer data surveyed, the major income sources of consumers were employment, labor, and handcrafts, trading, and farming in that order.

Start-up capital: The mean initial capital of sampled traders for buying the product from producer and selling to consumer was 1034.24 Birr and the current average capital circulating at hand of traders was 6568.4 Birr.

Monthly consumer's expense: The income of sample respondent per -month of a consumer varies from 893 to 10,000 for hotel owners and urban shopkeepers using enset products. It is a measure of the amount of money earned per household in the study area. The mean monthly income of consumer was 2208 birr, which is related to Ethiopian per capita income per year $=2792$ ETB) (UNDP, 2019). Apart from this, $25 \%$ of expense was used for kocho and bulla consumption.

\section{Institutional services}

Access to credit: The study result showed that about $28.1 \%$ of traders have credit from Omo microfinance and the remaining have got from family and local saving(Equb).

Access to transport: From respondent traders, $47.4 \%$ have to transport access to products which are road sided and the remaining use packing animal and hired and family labor force for product transaction.

Access to information: From 57 sampled; $77.2 \%$ traders have price information from relatives and daily operating yearround including the farming season in relation to a shortage of another cereal crop at different market outlets.

Access to training: From a total of sampled respondent traders $28.1 \%$ took training on marketing activities from cooperatives, Trade and Industry Office and OMO Microfinance Table 4 .

\section{Market participation characteristics of producer}

The average distance to market was 5.25 and 8.72 in kilometer to participants and non-participant respectively. The mean land size 2.0035 and 1.2083 hectares for participant and non-participant respectively. The quantity produced per

Table 4: Socio and demographic characteristics of consumers.

\begin{tabular}{|c|c|c|c|c|}
\hline Variable & Category & $\begin{array}{c}\text { Frequency } \\
(\mathrm{N}=66)\end{array}$ & $\begin{array}{c}\text { Percentage } \\
\text { (SD) }\end{array}$ & $\mathrm{X} 2$ /t-test \\
\hline Sex & $\mathrm{FHH}$ & 59 & 89.4 & $0.020 *$ \\
\hline Age & & 35.73 & 9.42 & \\
\hline Family members & & 4.62 & 2.02 & \\
\hline Education & Formal & 51 & 73.3 & 0.166 \\
\hline Marital status & Married & 54 & 81.8 & 0.290 \\
\hline Religion(discrete) & $\begin{array}{l}\text { Orthodox } \\
\text { Protestant } \\
\text { Catholic } \\
\text { Muslim }\end{array}$ & $\begin{array}{c}23 \\
45 \\
3 \\
-\end{array}$ & $\begin{array}{c}31.8 \\
68.2 \\
- \\
-\end{array}$ & 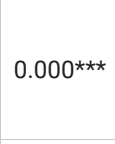 \\
\hline $\begin{array}{c}\text { Main source of } \\
\text { income(discrete) }\end{array}$ & $\begin{array}{c}\text { Farming } \\
\text { Trading } \\
\text { Employment } \\
\text { Labor } \\
\text { Hotel owner }\end{array}$ & $\begin{array}{c}5 \\
5 \\
21 \\
14 \\
21\end{array}$ & \begin{tabular}{c|}
7.6 \\
7.6 \\
31.8 \\
21.2 \\
31.8
\end{tabular} & $0.003^{\star \star}$ \\
\hline Monthly income of $\mathrm{HHH}$ & & 2208 & 2078 & $0.000^{\star * \star}$ \\
\hline Monthly product proportion & & 895 & 974.02 & $0.000 * * *$ \\
\hline
\end{tabular}

Citation: Haile A, Megerssa B, Negash R (2020) Enset (Ensete Ventricosoum) Value Chain in Dawuro Zone, Southern Ethiopia. Int J Agric Sc Food Technol 6(2): 126- 
household per year was 43.83qts and 23.08 for participant and non-participant respectively. Only $30 \mathrm{~kg}$ of Enset product, out of average 100kg yield per week was have used for value addition. The mean age of household head that participates in the market was 46.97 years; dominated by productive age. This data shows that age increase experience on the creation and alternative outlet choice increase to obtain a good price.

\section{Enset value chain actors and their functions}

The study result showed that, major traders of enset in the study area identified are, local collectors (28.1\%), wholesalers $(38.6 \%)$ and retailers $(33.1 \%)$ and the local collectors purchase enset products from producers and trading at farm get and local markets around and supplies them to wholesalers and retailers, in the order. Then after, wholesalers were purchased the products from producers at farm get and local market and local collectors thereby sold to retailers at Zonal level and wholesalers at out of Zonal level. Finally, consumers and hotels owner purchase from local collectors, wholesalers, and retailers. Supply of enset fluctuates in the summer season. Because of farming activities of the producer and its price increases. This implies throughout the year producers can harvest products but the quantity of supply varies from another season due to the farming activity of the farm household.

Value chain analysis systematically maps the actor participating in production processing marketing and consumption of a particular product. The value chain map is a conceptual and practical tool that helps us identifies policy issues that may hinder or enhance the function of a value chain and also the institutions and organization providing the services (such as market information and quality standards) that the different value chain actors need in order to make betterinformed decisions. The study result by [40] showed that valuechain map was made up of three interlinked components. These are, value chain actors, enabling environment (infrastructure, policies, institutions, and processes that shape the market environment), service providers (the business or extension services that support the value chain operations).

The value chain mapping enables to visualize the flow of the product from production to end consumer through various actors [41]. It also helps, to identify the different actors and their function in Enset value chain to understand their role, linkage as an analytical tool.In addition, it provides a useful framework forunderstandingkeyactivities, relationshipand mechanisms thatallowproducers,processors, buyers, sellersand consumers separated by time and spaceto gradually add value to products and servicesas they pass from one link of the chain to another making it, a "value chain" UNIDO [14].The present value chain map of study Woredas was has viewed in (Figures $4,5)$ as follows.

The crop production part root horticultural sub-sector is increasingly becoming an important sector in poverty reduction efforts by the improvement of households' incomes from sales of kocho and bulla products it creates an employment and improved nutritional status of families. Thus, enset products were the major income generating and poverty alleviation tools

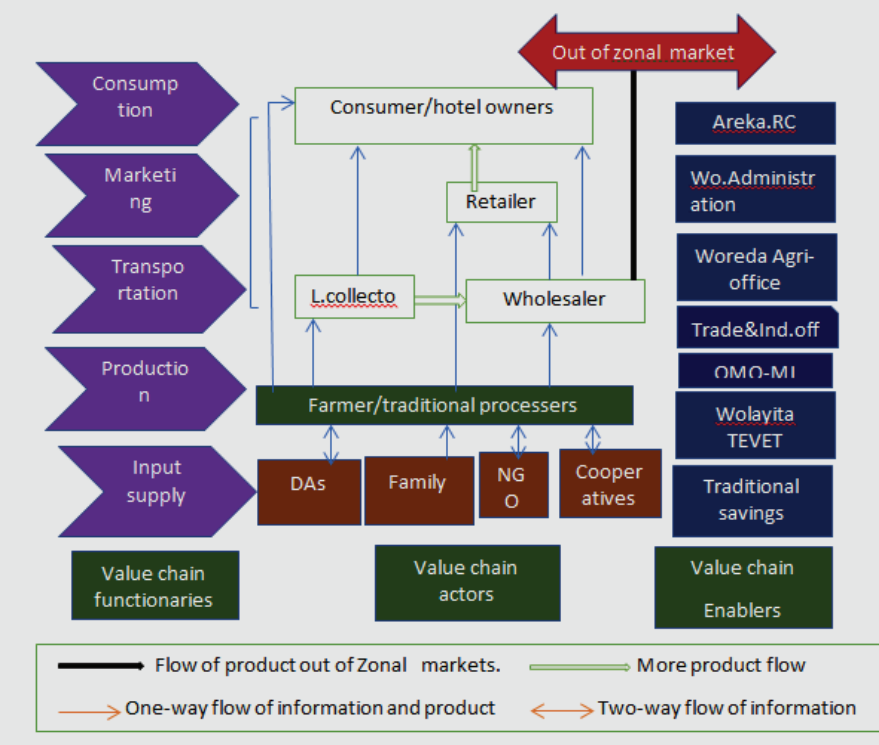

Figure 4: Value chain map of enset at study area.

Source: Own survey result (2019).

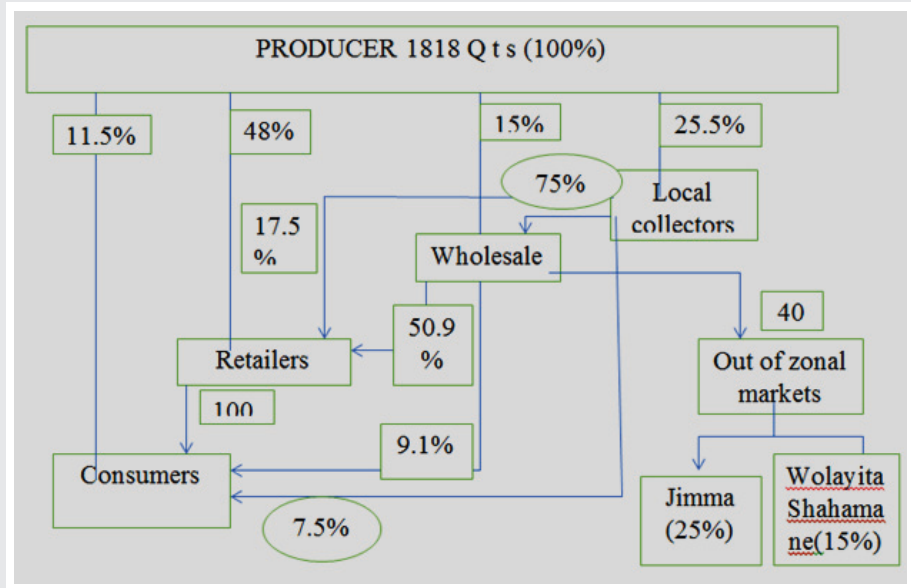

\footnotetext{
I. Producer $\rightarrow$ Consumer $\rightarrow(209.07 Q t)$

II. Producer $\rightarrow$ Retailer $\rightarrow$ Consumer (872 Qts)

III. Producer $\rightarrow$ Local collector $\rightarrow$ Wholesaler $\rightarrow$ Consumer (347.7Qts)

IV. Producer $\longrightarrow$ Wholesaler $\longrightarrow$ Retailer $\longrightarrow$ Consumer (138.8 Qts)

V. Producer $\longrightarrow$ Local collector $\longrightarrow$ Consumer (34.7Qts)

VI. Producer $\longrightarrow$ Wholesaler $\longrightarrow$ Consumer (24.81Qts)

VII. Producer $\longrightarrow$ Wholesaler $\longrightarrow$ Out of zonal markets (109.63Qts)

VIII. Producer $\longrightarrow$ Local collector $\longrightarrow$ Wholesaler $\rightarrow$ Retailer $\rightarrow$ Consumer (81.2Qts)
}

Figure 5: Kocho Marketing channel in Mareka and Loma Woreda.

Source:-Own survey result, 2019.

for smallholder enset producing farmers including traders in which enset was produced, processed, stored, packaged, transported and marketed. In each step, there was a value addition to fetch good price and value addition has taken to increase quality standard, make good for transporting the product. According to Anandajayasekeram and Berhanu (2010) [42], at each stage in the value chain, the product changes through chain actors, transaction costs have incurred and generally, some form of value has added. According to the above two Woredas value chain map from input suppliers NGOs and from value chain enablers the function of trade and 
industry office, Omo-micro finance function was not clearly seen at Mareka Woreda.

Input suppliers: Enset products value chain in the study area starts from the concept of production with the use of inputs to consumers and distribution of enset value added Kocho and Bulla. An input includes credit service, extension service agricultural instruments. Thus, input supplier's role had not clearly seen in the study area to encourage value addition along enset value chain except fewer amounts of credit and with less frequency of extension service according to the result of the study.

Producers Are the first most important direct actors along Enset value chain. More amounts of enset were having produced as food and a major source of income. Farmers use their own land, family labor, hired labor, wonfel , debo for production, plantation, weeding, thinning out, decorticating, processing transporting and marketing their products. The survey result revealed that $100 \%$ of sampled households were producing local variety.

Enset production per household: The maximum and minimum quantity of kocho produced per plant per year was 110 and 50 kilograms respectively. From this lot of produce 5 kilogram of bulla being produced per week per household via the value addition process of which 8 percent of bulla and 69 percent of kocho was being consumed at home by the producer and the rest was being sent to the markets. However, $35.5 \%$, $10.6 \%$ and $35.5 \%$ of respondents were challenged by lack of credit, distance to market and both lack to credit with lack of value addition experiences respectively. The value addition stage of enset at farmer level includes: -Enset-fiber kochosliced kocho-bread and Enset-row bulla simply supplied to market at study area.

Thus, the difference in the quantity of 'enset' produced and level of product value addition and market participation varies in the sampled household due to, management system, fertilizer application, and extension service, and labor availability, size of enset plantation in a hectare and value addition experience. Thus, $35.5 \%, 10.6 \%$ and $35.5 \%$ of respondents indicated that enset product market participation of producers was affected by, lack of credit, distance to market and both lack of credit with lack of value addition experience respectively. The value addition stage of enset at farmer level includes Enset $\rightarrow$ fiber 'kocho' $\rightarrow$ sliced kocho $\rightarrow$ bread and Enset $\rightarrow$ row bulla simply supplied to the market.

Local collectors: Enset products are the main profitable income generating for traders. Local collectors are collecting Enset specially Kocho in large proportion and Bulla in small proportion. They collect Kocho and bulla products from the producers at a farm gate and local market like Mari market day on Monday, Robi market day on Tuesday and on Monday of Mareka Woreda, Bale marketing center on Saturday, Koyesha market center on Thursday and Tulema marketing center on Sunday at Loma Woreda and from the area of producers. They purchase $1 \mathrm{~kg}$ of enset product Kocho 2 ETB and Bulla by 5 ETB respectively. The study result line with $[43,44]$ collectors was the most important channel between rural and urban markets.
Wholesalers: They played important role by purchasing enset products from producers and local collectors. Different activities performed by wholesalers along enset product value chain are, purchasing, packaging by enset shize and sacks (Madaberia). Most of the time wholesalers purchase kocho and Bulla from producers either from local or urban market center particularly Woreda urban center. They have distributed the produce to the urban center of the production area, Zonal market center, Out of Zone, out of Woreda (Jimma, Wolaita, and Shashamane). The market value of enset product is different in quality of product and different in market centers. They purchase Kocho at the price of $3 \mathrm{ETB} / \mathrm{kg}$ and Bulla $6 \mathrm{ETB} / \mathrm{kg}$ and sold to consumers and retailers at $4 \mathrm{ETB} / \mathrm{kg}$ and $10 \mathrm{ETB} / \mathrm{kg}$.

Retailers: They were actors play an important role. Their purchasing capacity was less than that of wholesalers and local collectors because of the shortage of initial capital for business. They purchase enset products from producers in large proportion in optimum price and sale to local collectors, wholesalers in small proportion thereby sold to consumers, hotels and by the price of 5 ETB Kocho and 11 ETB for 'Bulla'.

Consumers: Are end buyers and user of the product are those purchasing for consumption. Two types of consumers have identified. Those are households and hotel owners. They purchase from the producer, local collector wholesaler and from the retailer. The first consumers are employee's urban and rural residents who purchase and consume enset which have an average income of Birr 893 per month. Purchase enset product by 25 and $30 \%$ of their income in Mareka and Loma Woreda respectively. The Hotel owner buys the product and adds value us bread to sale with Kurt, meat product (burato, suluso, gomenbesga, kitfo, dulet), with milk and milk valueadded cheese product (Seliso, Uta, Tancho) and as porridge serves to the hotel servants. The survey result showed that, an average of $69 \%$ of kocho and $8 \%$ of bulla produced in 2019 consumed by the producers. The value-added products by consumers are, fiberkocho $\rightarrow$ sliced $\rightarrow$ bread, forage, mixed with teff as Enjera) and (Bulla $\rightarrow$ bread, souce, porridge).

\section{Service providers along enset value chain}

There are supportive service providers, which are providing, credit, extension service for producers. There were governmental institutions and non-governmental institution such as Agricultural office, Agricultural growth program (AGP), Sustainable land management program (SLM), Action aid Ethiopia, Marketing and cooperative office, Omo Microfinance and Areca Agricultural Research Center.

Most of the service providers involved in supplying inputs, producing, processing, marketing and consuming agricultural products Getnet [45]. They can directly have involved in the value chain (rural and urban farmers, processors, traders, retailers, hotel owners and consumers) or indirect actors who provide financial or non-financial support services, such as credit agencies, business service and government, researchers and extension agents. Since service provision is necessary for value chain actors to perform the activities that add value and reduce transaction cost. According to Martin, et al. [46], 
access to information, knowledge, technology, and finance determines the state of the success of value chain actors.

Extension service providers: The study result from sampled representative farmers revealed that the common service providers for producers at study area were, governmental institutions such as Agricultural Office, Development Agents, Agricultural marketing and cooperative office function on how to saving and information on a credit system. Areca Agricultural Research Center branch provide for farmer's awareness creation on Enset crop management, integrated diseases management system. Wolaita Technical Education Training College gives training for development agents.

Credit service providers: The data collected show that informal lenders play important role in accessing credit for farmers. In addition, farmers accessing credit from Omo Microfinance farmer's cooperative group and savings. The problem was that the credit system was not well developed, the commercial banks are predominantly state-owned and collateral based and private banks are not eager to finance agriculture in general and Enset production particularly. The reason was associated with highly traditional farming system of Enset production, unorganized market arrangement for Enset marketing activity and no private banks in the study area.

The main reason for most farmers not participating in credit was limited supply of credit and high-interest rate specially to take credit from omo Microfinance institution and less attention given to the sector. The survey result of respondents (44.1\%) revealed that Enset producers and Enset traders have obligatory to save $20 \%$ of the money in Omo Microfinance before getting credit from the institute and pay back with the interest rate of $8 \%$. Therefore, their participation in access to credit was limited and it is no more affordable for the actors in two studies Woreda.

Cooperatives: Trade and Industry office, marketing and cooperative office play role in small amount awareness creation. Trade and Industry office was given the license of trading whereas marketing and the cooperative office gave license of the presence of good storage space, for products, storing equipment. That was taken as criteria to be fulfilled by traders to keep the quality but according to trader's information; they trade with the license of flour. In the study area, the traders work without a license by women group savings and some with the license of floor trading. The cooperatives at Mareka Woredas are simply grouping female traders and Loma Woredas cooperative started with group saving and credit for traders but in two Woredas no cooperatives which collect the product. The two-way flow at Loma Woreda is saving, credit and information flow. On side of Mareka Woreda only information flow to farmers by grouping them but no giving credit for the product trading.

\section{Value chain governance of enset actors}

The known value chain actor's play facilitating role, they were determining the flow of product and level of price by doing this, and they govern the value chain and most of other chain actor's subscribes the rule set in the marketing process Table 5 .

The result of this study indicates that wholesalers and

\begin{tabular}{|c|c|c|c|}
\hline Table 5: Frequency of price setting by actors. \\
\hline Actors & Frequency & percent & $\boldsymbol{x}^{2}-$ test \\
\hline Producer & 30 & 20 & \\
\hline Traders & 84 & 55 & $0.012^{\star \star}$ \\
\hline Negotiation & 38 & 25 & \\
\hline Total & 152 & 100 & \\
\hline
\end{tabular}

Source: Own data competition result (2019)

collectors influence the retailer and producer by controlling price movement and more by giving cash extending system and mostly Gessa market in Loma Woreda was highly influenced. The two markets namely Gessa and Tercha are heavily depending on Enset market to out of different markets found in Dawuro zone. According to the study, producer farmers have lack of appropriate market information and less bargaining power. Power irregularity is central to value chain governance (Kaplinsky and Morris, 2001). Therefore, greater than $55 \%$ of the producer sells their produce offered price by traders and only about $20 \%$ producer's sale price offered by themselves and the remaining $25 \%$ sale by negotiation.

The result of the study indicates that; the producers are price takers. With these traders of Gessa market replay Wolaita Sodo market traders for price setting, traders of Tercha market most of the time look hotel owners and Jimma wholesalers at the market day. There is no vertical linkage between the value chain actors of enset but there is a horizontal linkage between traders among the producer and trader's commitment. The study result of actor's response shown that good quality from the producer needed and good price from the trader accepted. However, producers are not providing a quality product and the producer blame that the traders do not give us a good price Table 6.

\section{Enset productivity and marketing at study woredas}

Most of the farmers live in Mareka and Loma Woreda highland area are producing Enset on a mean of 0.599 and 0.631 hectares of land respectively. Having this, farmers produce a yield mean of 38.08 quintals Kocho and 1.99 quintals bulla per year at Mareka and Loma Woredas respectively. The result has shown in the volume of 'enset' production and land allocation for the product Loma Woredas is in a better position.

According to the study result, smallholder farmers produce row Kocho ('uncha) with fiber and bulla (etma) from the filtered flood of Enset internal part. Bulla is free from any fiber with less amount of water and sometime dried with good preparation and packaging material. The data conducted show that Kocho was used for home consumption $(69 \%)$ and $(31 \%)$ is supplied to market in the form of fiber kocho or sliced form and sometime in the little amount on bread form. From bulla, produced $(8 \%)$ were consumed at home level for traditional 
festivals and for mothers giving birth as supplementary food and $(92 \%)$ of 'bulla' is supplied to near or far market outlets Table 7.

Table 6: Productivity of Enset at study area.

\begin{tabular}{|c|c|c|c|c|c|c|c|}
\hline \multirow{2}{*}{ Item } & \multicolumn{2}{|c|}{ Loma(N=69) } & \multicolumn{2}{c|}{ Mareka(N=83) } & \multicolumn{2}{c|}{ Total(N=152) } \\
\cline { 2 - 8 } & Mean & STD & Mean & STD & Mean & STD \\
\hline $\begin{array}{c}\text { Land allocated for enset } \\
\text { Frequency of harvest per month }\end{array}$ & 0.631 & 0.3245 & 0.572 & 0.2992 & 0.599 & 0.3113 \\
\hline $\begin{array}{c}\text { Bulla produced /year /HH in } \\
\text { quintal's }\end{array}$ & 2.43 & 1.498 & 1.99 & 1.496 & 2.21 & 1.808 \\
\hline $\begin{array}{c}\text { Kocho produced per HH/year in } \\
\text { quintals }\end{array}$ & 39.01 & 12.936 & 38.08 & 16.455 & 38.51 & 14.920 \\
\hline
\end{tabular}

Table 7: The quantity of enset supplied to market and price.

\begin{tabular}{|c|c|c|c|}
\hline Enset product & Unit & Quantity supplied to market,2019 & Average price \\
\hline Kocho (5853) & Quintal & $1818(31 \%)$ & 500 \\
\hline Bulla (184) & Quintal & $164(92 \%)$ & 1000 \\
\hline
\end{tabular}

NB; Local user were converted to quintals.

Source: Own survey result (2019)

\section{Enset marketing channels at study woreda}

The analysis of marketing channels could intend to provide a systematic knowledge of the flow of goods and services from its origin of production to final destination Abraham (2013).

Kocho marketing channel: The survey result showed that, eight marketing channels were observed in the study area. From which producer- retailer - consumer channel was the largest one identified in the study (48\%). All chains in study area start with production stretches to consumption where input suppliers were involved to boost value addition along the chain. Here, smallholder farmers with average land holding of 0.5 hectares per household have dominated the production levels.

I. Producer and Consumer: Through this market channel, about $11.5 \%$ (209.07 Qt) of kocho was marketed during the period as data collection. This channel was third important channel during the trading according to volume and it was a relevant channel to the producer to get a good price from producers without intermeddlers and good for consumers in term of price.

II. Producer, Retailer, and Consumer: Through this market channel about $48 \%$ (872qts) of kocho was marketed during the period of the survey. This is the first important channel in which more of produce pass through it. In this channel, retailers perform better by direct contact with producer and selling the produce to the consumer and obtain a better share of profit by gathering more amounts from producer and trading it to the near market consumers.

III. Producer, Local collector, Wholesaler and Consumer: With this channel, about 19\% (347.7qts) of kocho was marketed during the period. In this, channel a large amount of kocho sold to the consumer and it is the second existed in the study area.
IV. Producer, Wholesaler, Retailer and Consumer: In this channel, about $14 \%$ (138.8qts) of kocho was marketed during the period. It is the fourth important channel in term of volume of produce pass through it.

V. Producer, Local collector and Consumer: In this channel, about $2 \%$ (34.7qts) of kocho marketed during the period. This is the seventh-important channel less amount of produce pass through it. In this, channel wholesalers perform better by collecting the produce from local collectors and selling the produce to out of zonal markets and get better profit.

VI. Producer, Wholesaler, and Consumer: With this channel, about $1.4 \%$ (24.81qts) of kocho marketed during the survey period. This channel is the last channel in term of volume pass through it.

VII. Producer, Wholesaler, and Out of zonal markets: With this channel, about 5.8\% (109.63qts) of kocho marketed during the period according to study data. This is the fifth important channel with this all produce pass through out of zonal markets. While more benefit shares to wholesalers directly contacting the producers and selling out zonal markets.

VIII. Producer, Local collector, Wholesaler, Retailer and Consumer: With this channel, about 4.5\% (81.2qts) of kocho marketed during the period as collected. This is the sixth important and longest channel with this, less amount of produce pass through it and more of intermediaries are there until the product reaches to the consumer.

\section{Bulla market channel}

Seven marketing channels were identified for bulla market were producers, retailers and consumers carry largest volume of the produce, followed by producers, local collector's wholesalers. From the total 184 Qt produced in 2019169 qt was supplied to local and terminal market and apart from this 54.7 Qt traded to out of zonal market Jimma, Wolayita, and Shashemene. While the reaming amount flow through the identified marketing channels to consumers and hotel owners (Figure 6).

I. Producer and Consumer channel: $18.5 \%$ (30.5qts) of bulla marketed during the study period and this channel was the third important channel in term of volume and it was a relevant channel to the producer to get a good price from producers without intermeddlers.

II. Producer, Retailer, and Consumer channel: this is the first important channel where $39.2 \%$ (67.07qts) of bulla marketed during the period of the survey. This is the first important channel more of produce pass through it. In this channel, retailers perform better by direct contact with producer and selling the produce to consumer.

III. Producer, Wholesaler, and Consumer channel: this is channel, which is least significant by contributing $2.5 \%$ (4.18qts) of bulla pass through it.

IV. Producer, Wholesaler, and Terminal markets: this is the fourth important channel where $14 \%$ (23.7qts) of bulla 


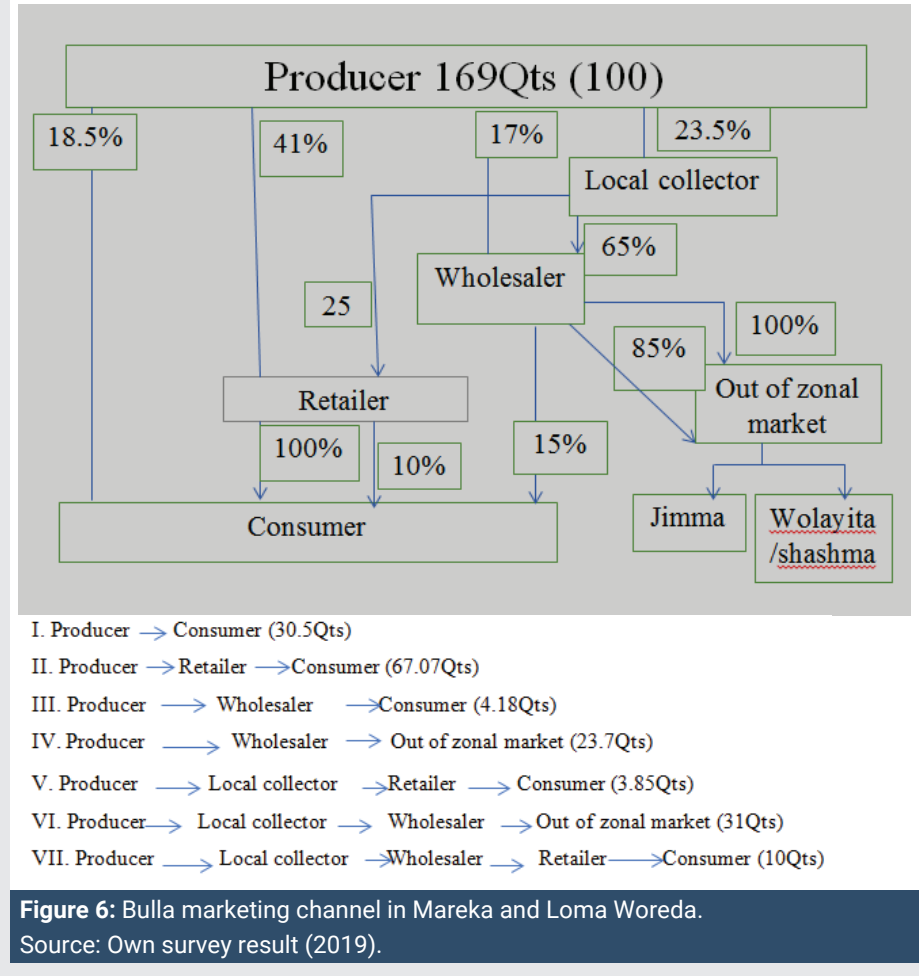

was marketed during the period. In this, channel wholesalers perform better by direct contact with producer and selling the produce to out of zonal markets and get better profit.

V. Producer, Local collector, Retailer and Consumer channel: this is six channels which contributed $2.27 \%$ (3.85qts) of bulla to the marketed during the period. This is the last channel less amount of produce pass through it and high amount of intermediary.

VI. Producer, Local collector, Wholesaler and Terminal market: This is the second -most important channel where $18 \%$ (31qts) of bulla was supplied to market. In this, channel wholesalers perform better by collecting the produce from local collectors and selling the produce to out of zonal markets and get better profit.

VII. Producer, Local collector, Wholesaler, Retailer and Consumer: This is the fifth important and longest channel which assisted for supply of $5 \%$ (10qts) of bulla to market during the period. With this, less amount of produce passes through it and high numbers of intermediary.

\section{Share of benefits along enset value chain}

The Performance of enset market: The study indicated that, from the total performances of enset market was evaluated by considering associated returned -costs and costs from production to marketing. Hence, analysis of margin was identified by comparing cost-benefit analysis and marketing margin of actors. From the study result, kocho and bulla produced in 2019 were 5853 and 184 quintals respectively and from the produced $1818 \mathrm{ql}$ (31\%) Kocho and $169 \mathrm{ql}$ (92\%) Bulla supplied to the market.

To this study, distribution of cost and gross income at different level was evaluated in the business of enset. The marketing of the product mainly involves the cost of postharvest activities incurred before reaching the end consumer and hotel owners. This includes the cost of harvest and packaging (material and labor costs) handling clearing from the fiber (loading and unloading) and transportation cost. This is in line with [47] reported that, costs which are incurred to perform various marketing activities in the transportation of goods from producer to consumers.

Thus, the component constitutes a large share in the total margin between the final retailer price and the cost of production. Therefore, the margins calculation is done to show the distribution of cost and benefit throughout the various actors as enset product moves from producers to local collectors, wholesalers, retailers and finally to consumers. Marketing margin has been used to measure the share of the final sailing price which has captured by each actor in the value chain. The relative size of various market participants gross margin can indicate where in the marketing chain value-added.

The study conducted by Enibe, et al. [48] on Banana Market in Anambra State Nigeria showed that, marketing margin as the difference between the consumer price and the price received by producers. In order to calculate marketing margins of an agent, the average price of enset product for that agent was taken. For instance, the buying price of consumer and hotel owners was obtained by taking the average purchasing price of the consumer in order to measure the market share of each agent. Similar studies were conducted by Takele [22] showed that, marketing margins as average selling price minus average buying price. The marketing channels of all actors have participated was identified according to product flow.

Kocho market performance: Cost and price information was computed to construct marketing cost and margin. Therfore, total gross marketing margin (TGMM) was worked out to identify final price paid by end buyer. Consequently the result indicated that, chain actors had added value to Kocho as the exchange takes place from one actor to another. To this effect, actors through changing the form of produce i.e from enset to bulla and amciho and baking; and by improving grades through sorting, cleaning fiber, transporting and packing in clean sheath, plastic, plastic bags. This result line to Chaka, et al. [25] who illustrated restaurants and hotels were involved to sell food stuffs and likewise farmers and traders were participated in improving quality for better profit Table 8 .

Compared to farmers, traders (local Collectors, wholesalers, and retailers) expense is about $60 \%$. However, the profit margin of a trader is more than $76 \%$ that of the farmer.

The result shows that kocho traders are simply buying from the farmers at the different outlet of product and selling to consumers, and earn $74 \%$ of the total profit margin. Hence, farmers operating all work from plantation up to market taking challenges and risks in production had only $26 \%$ of the profit margin. This miss share of benefit happened with the factors affecting farmers on value addition and level of market participation. Therefore, enset producers added only $26 \%$ local 
collectors, wholesalers and retailers add up to $27 \%, 22 \%$, and $25.08 \%$ respectively, and the change of producer's price to consumer price interval is $68 \%$.

Marketing margin of Kocho at different market channels: The result of study area shows that Marketing margin of Kocho has eight channels in each group of market actors are given in Table 9; GMMF, GMMc, GMMw, and GMMr are gross marketing margins of farmers, local collectors, wholesalers, and retailers respectively.

Table 9 depicts that, total gross marketing margin (TGMM) of Kocho is highest at III, VIII and VII that is about $84 \%, 80 \%$, and $75 \%$ respectively. In channel I, V and VI have the highest gross marketing margins $100 \%, 55 \%$, and $45 \%$ respectively. At first channel (I), producer directly sells the product to the consumer. The share of farmer (GMMF) is the highest (100\%) and lowest price in channel III, VI and VIII about 16\%, 25\% and $20 \%$, because of more intermediation of wholesalers, local collectors and retailers at marketing channel purchasing from the producer at farm gate and local market by lower price and sell to urban consumers and hotel owners by taking high price.

Bulla market performance: Table 10 illustrates that a different type of marketing cost and margin related to the transaction of bulla by farmers, local collectors, wholesalers, and retailers. The arrangements of costs are the same as Kocho value chain. While the study shows that enset value chain actors in bulla have the same value adding behavior as Kocho value chain actors.

In addition, the farmer operating from farming up to marketing gets the value of less than $25.95 \%$. While the share of the profit margin of local collectors, wholesalers, and retailers were $25.32 \%, 22.15 \%$, and $26.58 \%$ respectively from the sales of one quintal of the bulla. This implies that retailers of bulla were benefiting more than other actors in the marketing of

Table 8: Kocho marketing cost and benefit share of actors.

Item(Birr/Quintals) Producer Local collator wholesaler Retailer Total

\begin{tabular}{|c|c|c|c|c|c|}
\hline Production cost & 90 & - & - & - & 90 \\
\hline Purchasing price & - & 220 & 300 & 350 & 840 \\
\hline $\begin{array}{l}\text { Marketing cost } \\
\text { - Material cost } \\
\text { Plastic sheet, } \\
\quad \text { Sacs(malaria) } \\
\text { - Baskets } \\
\text { - Transport } \\
\text { - Overhead cost } \\
\text { - Loss } \\
\text { - Labor cost }\end{array}$ & $\begin{array}{l}2 \\
- \\
3 \\
3\end{array}$ & $\begin{array}{l}5 \\
5 \\
5 \\
2\end{array}$ & $\begin{array}{c}5 \\
10 \\
3 \\
5\end{array}$ & $\begin{array}{l}5 \\
- \\
6 \\
2\end{array}$ & $\begin{array}{l}17 \\
15 \\
17 \\
12\end{array}$ \\
\hline Total marketing cost & 8 & 25 & 32 & 13 & 78 \\
\hline Total cost & 98 & 225 & 282 & 353 & 958 \\
\hline Sales price & 180 & 325 & 400 & 440 & 1345 \\
\hline Marketing margin & 90 & 105 & 100 & 90 & 385 \\
\hline$\%$ Share of Margin & 23.4 & 27.27 & 25.97 & 23.4 & 100 \\
\hline Profit Margin & 82 & 80 & 68 & 77 & 307 \\
\hline \%Share of profit & 25.92 & 27 & 22 & 25.08 & 100 \\
\hline
\end{tabular}

Source: Own survey result (2019)
Table 9: Benefit distribution of actors in different marketing channels of Kocho

\begin{tabular}{|c|c|c|c|c|c|c|c|c|}
\hline $\begin{array}{l}\text { Market } \\
\text { Margin }\end{array}$ & I & II & III & IV & V & VI & VII & VIII \\
\hline TGMM & 0 & 64 & 84 & 70 & 45 & 55 & 75 & 80 \\
\hline GMMF & 100 & 36 & 16 & 30 & 55 & 45 & 25 & 20 \\
\hline GMMc & - & - & 34 & - & 45 & - & - & 28 \\
\hline GMMw & - & - & 46 & 55 & - & 55 & 75 & 38 \\
\hline GMMr & - & 74 & - & 15 & - & - & - & 14 \\
\hline
\end{tabular}

Source: Own survey result (2019)

Table 10: Bulla marketing cost and benefits distribution

Item(Birr/Quintals) $\quad$ Producer Local collector Wholesaler Retailer Horizontal

\begin{tabular}{|l|c|c|c|c|c|}
\hline Production & 170 & - & - & - & 170 \\
\hline Purchasing & - & 400 & 550 & 600 & 1550 \\
\hline
\end{tabular}

Marketing cost

- Material cost

- Transport cost

- Overhead cost

- Loss

10

10

\begin{tabular}{l|l|l}
\hline 5 & 10 & 30
\end{tabular}

10

Labor cost

-

Total cost

195

Sales price

$$
400
$$

Marketing Margin

$$
230
$$

\%Share of Margin

25.27

Profit margin

$\%$ Share of profit

$$
205
$$

$-$

20

5

$10 \quad 70$

- 5

$10 \quad 20$

Source: Own survey result (2019)

bulla value chain. Thus, the shares of the producer are only about $25.95 \%$ of all according to the study; benefit distribution goes through different actors through value-adding simply from the producers. The retailers due to small operational cost earn the highest profit. The study by [32] shows that from enset value chain, retailer's share of profit is high due to small operational cost.

Table 11 emphasizes that distribution of benefit along bulla value chain varies from marketing channels in which product has distributed to actors. Thus, one can see that the total gross marketing margin (TGMM) is highest at channel VII $81.6 \%$ and lowest in channel I, II and III $0 \%, 59 \%$ and $63 \%$ respectively. The total marketing margin of producer (GMMF) in channel I is $100 \%$ producers sold directly to the consumer at a better price, and there are no intermediates in this channel. Wholesalers got the highest marketing margin at channel IV, III, VI $67 \%$, $63 \%$ and $40 \%$ respectively and the lowest marketing margin at channel VII accounts about $39 \%$. The retailers got highest gross marketing margin at channel II and V and lowest at marketing channel VII. This implies that retailers in the study area are incurring less marketing cost and benefit more in these two channels than other channels by buying from producer list cost and lodging extra price on hotel owners and consumers.

\section{Factors affecting market participation of producers}

For food crop, a producer selling only whatever surplus 
product left after household consumption requirements are met Birhanu (2014). In case, all farmers participate (OLS), the model was applicable, but in preliminary observation of the study area, not all farmers participated in enset supply to market. Tobit model was used to identify determinants of farmer's quantity supply and level of participation to market. The Tobit model in a one-step approach in the assumption was applicable. So that, the same set of parameters and variables determine both the quantity of supply and level of market participation [49].

Thus, the overall significance and fitness of the model have been checked by the value of pro $>c h i^{2}=0.000$ which shows that the result is significant at less than $1 \%$ level of significance. The logpseudo, likelihood value of -380.5037 have shown that the assumption of the null hypothesis that all predictors in the regression model are together equal to zero was rejected at less than $1 \%$ level of significance. Out of 15 explanatory variables included in the model, 8 variables were found statistical significance at the different level of significance. From the variables used in the model family size, distance to nearest market and incidence to disease determines the level of market participation negatively and other variables used in the model such as, education level of household head, access to market information, yield per hectare, consumer preference, access to transport facility and price are determined to level of market participation of the producers positively.

Education level positively affects farmers' market participation at $5 \%$ level of significance as indicated in (Table 12). As the level of education increases, the tendency of farmer's market participation increases. The marginal effect of the model also realizes that education level of household increases by one-year enset product supply to market and level of farmer's market participation increases by $77.2 \%$. Education was believed to give individuals with necessary knowledge that can be used to collect information, interpret the information make good production and supply decision to the market. In line with this, Berhanu, et al. (2011) assert that household heads who attended formal education have good information in value addition and market participation. In addition [33] realizes that education is one of the facilities to rural people to overcome poverty and activate business.

Distance to nearest market affects farmer's participation negatively at less than $5 \%$ significance level. The result shows that farmers far from the market by 1-kilometer decrease participation to market; the increase in a unit kilometer distance reduces the actual amount of 'enset' supply condition to market by $5.16 \%$. This is due to lack of transportation facility and 'enset' products are bulk and high water content to transport long distance. This study also agrees with Tadesse [50] which describes that distance to market caused a surplus of avocado in Gomma Woreda. This result also lines with the finding of soybean market participation by smallholder farmers in Zimbabwe in which distance to market negatively influences smallholder farmer's extent of market participation [51].

Access to market information also affects kocho and bulla
Table 11: Benefit distribution of actors in bulla marketing channels.

\begin{tabular}{|c|c|c|c|c|c|c|c|}
\hline $\begin{array}{l}\text { Market } \\
\text { Margin }\end{array}$ & I & II & III & IV & V & VI & VII \\
\hline TGMM & 0 & 59 & 63 & 67 & 70 & 73 & 81.6 \\
\hline GMMF & 100 & 41 & 37 & 33 & 30 & 27 & 18.4 \\
\hline GMMc & - & - & - & - & 38 & 33 & - \\
\hline GMMw & - & - & 63 & 67 & - & 40 & 60 \\
\hline GMMr & - & 59 & - & - & 32 & - & 53 \\
\hline
\end{tabular}

Source: Own survey result (2019)

Table 12: Result of Tobit regression model.

\begin{tabular}{|c|c|c|c|c|c|}
\hline Variable & $\begin{array}{c}\text { Marginal effect } \\
\text { of } E\left(y^{*} / y>0\right)\end{array}$ & Std.err & $P>z$ & $\begin{array}{c}\text { Marginal } \\
\text { effect } \\
\text { ofPr }(y>0)\end{array}$ & $\begin{array}{c}\text { Marginal } \\
\text { effect of } E(y / \\
y>0)\end{array}$ \\
\hline GNDR & .4571435 & 1.04292 & 0.661 & .0088834 & .5564339 \\
\hline AGE & .0743484 & .04581 & 0.105 & .0013968 & .0900591 \\
\hline FSIZE & -.4052876 & .24486 & $0.098^{*}$ & -.007614 & -.4909294 \\
\hline EDFRYR & 2.277688 & .62873 & $0.000^{\star \star \star}$ & .0427901 & 2.758989 \\
\hline ACCCRDT & .2518701 & .9433 & 0.789 & .0047075 & .3048653 \\
\hline DCEMKT & -.1022456 & .0574 & $0.075^{\star}$ & -.0019209 & -.1238513 \\
\hline ACSMINFO & 1.508321 & 1.04076 & 0.147 & .0267992 & 1.812053 \\
\hline LNDSIZE & .1857706 & .47593 & 0.696 & .00349 & .225026 \\
\hline YLDPRHY & 1797901 & .04155 & $0.000 \star \star \star$ & .0033777 & .2177817 \\
\hline CNSPRFNC & 5.768192 & 1.06444 & $0.000 * \star \star$ & .1841343 & 7.604916 \\
\hline OFFAC & -.5727845 & 1.0458 & 0.584 & -.0103385 & -.6898717 \\
\hline EXTFRCO & .0164098 & .31954 & 0.959 & .0003083 & .0198773 \\
\hline ACSTFCLT & 3.265065 & .96309 & $0.001^{\star \star \star}$ & .0700519 & 4.026187 \\
\hline ICDSEASE & -2.454859 & 1.1163 & $0.028 * \star$ & -.0376311 & -2.890947 \\
\hline PRICE & 5.753948 & 1.0869 & $0.000 * \star \star$ & .2142195 & 7.841389 \\
\hline Constant & -14.74115 & 4.145739 & & & \\
\hline Sigma & 5.952148 & .406792 & & & \\
\hline
\end{tabular}

OBS. Summary Left-Censored observation $=39$ Right - Censored obs $=113$

Number of Obs $=152$ LR Chi2 $(15)=197.79$ PR $>$ Chi2 $=0.0000$

Log likelihood $=-380.5037 \quad$ Pseudo R2 $=0.2063$

Source: Own data computation result (2019)

market significantly at $5 \%$ level of significance. On average, producers get market information, the number of participant in the market increases. Thus, the degree of information increases by extent, the actual number of kocho and bulla producer's market participation increases by $8.63 \%$ with the increased presence of information to the producer. In line with this [36] studied the extent of market participation among yam producers in North area of Nigeria revealed that access to market information significantly and positively influences yam producers market participation. The information helps to supply more and increases farmer's participation in the market, according to Mohomed (2011) household increases the marketable supply of teff significantly in Halaba especial Woreda. Therefore, Farmers who have price information prior to marketing tend to sell more of their products than those without.

As hypostasized, the result shows that farmer's market participation significantly affected by quantity produced per 
year at $1 \%$ the level of significance positively. The positive coefficient revealed that a unit increase in the quantity of produced increases farmer's participation in the market. Hence, a unit increase on kocho and bulla produced the actual amount of kocho and bulla supply to the market increases by $3.12 \%$. This indicates that an increase in enset product yield per year by a quintal results increase in the level of market participation because this was explained by the fact that those smallholder farmers with more harvest were in the better position to sell more kocho than earlier sales.

In agreement with this [52] South Africa and Niger were households with larger maize harvests were likely to have more surpluses for sale and more participation to market. In addition, the study by Cunguara, et al. [53] realizes that increases in the proportion of households producing these crops which indicate that increased market participation was accompanied by increased production. This finding is similar to the finding of [30] because households with a higher value of produced crop sell a higher proportion of their products and thus, increase participation in the market.

Consumer preference is dummy variable which had a positive impact and statistically significant at $1 \%$ level. This shows that the number of supply increases in response to the consumer. Thus, consumer preference increases by one unit than the actual farmer's participation to market and likelihood increases by $11.61 \%$. Thus, consumer preference for value-added enset production increases market participation of producers. In this regard [54] explained that from social and cultural factors consumer preference to output market increases farmers' market participation of producer.

Off-farm, activity has a negative influence on the volume of kocho supplied to the market at less than $5 \%$ level of significance and the result shows that increase in the quantity of off-farm caused decreased farmer market participation on enset product. Nuri, et al. [55] support this in explaining that income from non/off-farm has a negative relationship with the 'kocho' market participation. The result of Tobit regression model shows that a unit increases in off-farm activity decreases the farmer's participation in 'enset' product market by $8.23 \%$. This result shows that farmers engaged in off-farm activity to earn income other than enset. Thus, they tend to reduce more time to produce other crop and off-farm activity than enset production. The study similar to [23] realizes that off-farm income in total annual household income positively related to the participating in the maize market, it is negatively related to the quantity of maize sold.

Access to transport facility had also a positive impact on market participation and statically significant at $10 \%$ level of significance. This implies that access to transport facility increases producers market participation. Therefore, the access to transport facility and own packing animals increases the actual amount of kocho and bulla supplied to market by $7.98 \%$. So, it hypostasized to affect farmer's participation positively and significantly. If there are no means of transport, they do not participate in the market due to different costs. In line with this study Weisbrod [56] explains the ideas by imposing an effective limit on output raising travel times and costs, reducing reliability and diminishing access to the product. Moreover, in line with this [57] conducted study on potato value chain and indicated that the availability of transportation facilities helps to reduce long market distance constraints, offering greater depth in marketing choices

The incidence of disease was dummy variable which had a negative impact and statically significant at the level of less than $5 \%$. This shows that by keeping other explanatory variables constant, the incidence of disease in production year reduces farmer's market participation to the market the marginal result of Tobit regression also explained that, with a unit decrease by the incidence of disease reduces the actual amount of supply to market by $8 \%$. In agreement with this study [37] explained that 'enset' bacterial wilt is a major constraint to enset production in Ethiopia endangering the livelihoods of millions of farmers and threatening the food security of over 15 million people for whom enset was a staple food and source of income.

In addition, the study conducted by illustrates that Enset (Xanthomonal wilt) disease rated the first in its devastation. Another study by [58] shows that, low level of improved agricultural technologies, risks associated with weather conditions, diseases and pests are the main reasons for low productivity.

Price influence farmer's participation positively and it is significant at $1 \%$ level. When, price increases by one Birr, the level of market participation increases. The regressions of the model also described that a unit increase in price increases the actual increase of participation by $8.3 \%$. In relation to this [59] conducted a study on horticultural crop pineapple emphasized that better output price is the key incentive for the sellers to supply more to the market. Therefore, higher price perceived to increase the extent of market participation of enset producers $[60-75]$.

\section{Market outlet choice of producer}

Factors affecting enset market outlet choice of producer: The multivariate probit model is the generalization of the probit model used to estimate several correlated binary outcomes jointly. The syntax mv probit estimates the multivariate probit model. The parameter estimates are simulated maximum likelihood (SML) estimators. The marginal success probability for each equation is estimated by the command mvppred varnnam, pmarg. The command mvppred, pa computes the joint probabilities of all equation success or failure [75-100].

Table 13 shows that, there are four outlet choices to the producer which are wholesalers, collectors, retailers and direct consumer outlets. The sample was drawn 5 times since; simulated maximum likelihood estimate was computed from the parameters estimated as the sample drawn. The matrix Rho21, Rho31, Rho32, and Rho42 were shown that the correlation coefficient matrix between farmer direct consumer, farmer collector, farmer retailer and farmer wholesaler respectively. The likelihood ratio test computed result shows that the correlation coefficients are statistically different from zero in one of the four causes which indicate that the appropriateness 
Table 13: Model outputs of multivariate probit for determinants of outlet choice.

\begin{tabular}{|c|c|c|c|c|c|c|c|c|}
\hline \multirow{2}{*}{ Variables } & \multicolumn{2}{|c|}{ Concumer } & \multicolumn{2}{|c|}{ Wholsaler } & \multicolumn{2}{|c|}{ Retailers } & \multicolumn{2}{|c|}{ Collector } \\
\hline & Coef. & Std.err & Coef. & Std.err & Coef. & Std.err & Coef. & Std.err \\
\hline AGE & -0.00828 & 0.012 & $-.02184^{\star}$ & 0.012 & .00586 & 0.011 & -.00371 & 0.013 \\
\hline EDFRYR & -.410834 ** & 0.169 & .11128 & 0.171 & -.03414 & 0.15 & .20094 & 0.193 \\
\hline DCEMKT & -.00252 & 0.017 & 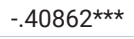 & 0.016 & $.04203^{\star \star \star}$ & 0.015 & .00408 & 0.018 \\
\hline ACSMINFO & -.22876 & 0.273 & -.04625 & 0.285 & -.38415 & 0.268 & .40926 & 0.300 \\
\hline EXTFRCO & .04608 & 0.077 & 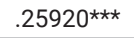 & 0.085 & -.01497 & 0.077 & $.34286 * \star \star$ & 0.099 \\
\hline PACKAOW & -.04890 & 0.242 & $.30956^{\star \star}$ & 0.259 & $-.433236^{\star}$ & 0.240 & -.07574 & 0.276 \\
\hline PRICE & $.00067^{\star \star \star}$ & 0.001 & $.66088^{\star \star \star}$ & 0.002 & $-.00278 * \star$ & 0.001 & $.00624^{\star \star \star}$ & 0.001 \\
\hline LABOUR & .22197 & 0.013 & -.00397 & 0.013 & .20284 & 0.012 & 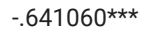 & 0.015 \\
\hline OUTPUT & $.02928 * \star \star$ & 0.240 & .00454 & 0.356 & .02503 ** & 0.236 & $.03955^{\star \star \star}$ & 0.294 \\
\hline _cons & -1.0239 & 0.905 & 1.0130 & 0.897 & -.70092 & 0.862 & $-3.9290 * \star \star$ & 1.116 \\
\hline Predicted probability & & 0.29 & & 0.44 & & 0.38 & & 0.69 \\
\hline rho21 & & \multicolumn{7}{|c|}{-0.205} \\
\hline rho31 & & \multicolumn{7}{|c|}{-0.0695} \\
\hline rho41 & & \multicolumn{7}{|c|}{$-0.31 * \star$} \\
\hline rho32 & & \multicolumn{7}{|c|}{$-0.422^{\star \star \star}$} \\
\hline rho42 & & \multicolumn{7}{|l|}{-0.116} \\
\hline rho43 & & \multicolumn{7}{|c|}{0.161} \\
\hline Wald chi2(36) & & \multicolumn{7}{|c|}{ 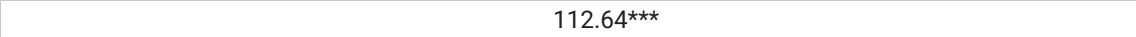 } \\
\hline chi2 (6) & & \multicolumn{7}{|c|}{$17.95^{\star \star \star}$} \\
\hline Log-likelihood & & \multicolumn{7}{|c|}{-309.49} \\
\hline Likelihood ratio test & & \multicolumn{7}{|c|}{ rho $21=$ rho31 $=$ rho $41=$ rho $32=$ rho $42=$ rho $43=0$} \\
\hline Joint probability of success & & \multicolumn{7}{|c|}{0.0229} \\
\hline Joint probability of failure & & \multicolumn{7}{|c|}{0.0543} \\
\hline
\end{tabular}

of the multivariate probit specification and outlet choices of 'enset' producers was mutually interdependent. The Wald chi2 test value 112.64 is significant. The separate estimation of 'enset' farmer's outlet choice is biased and the choice decisions to choose the four outlets were interdependent.

The choice of farmers to consumer's outlet was significantly affected by education level of the household negatively. Since educated farmers no more want to choice consumer outlet they choice traders and positively affected by more of output produced and price. The predicted probability to choose consumer outlet was $29 \%$. From factors which influence wholesaler market were the age of household head, distance to market, extension frequency contact, access to transport facility and price were significant.

The choice of the farmer to wholesaler market outlet was influenced by extension frequency contact and price positively. Because of extinction contact number increases and supply to wholesaler increases with the increased price per quintal. In addition, the choice of wholesale market negative influenced by labor and output. Since there was a high amount of labor and output, they want to sell to collectors. The predicted probabilities of choosing Wholesaler outlet was 44\% [100-120].

From factors that affect retailers market outlet choices distance to nearest market and output of produced are significant positively. Packing animal owner and price are negative to the choice of retailer market. The predicted probability of choosing retailer's market outlet was 38\%. This is due to retailer's purchase from producers at farm gate and local markets with low price.

The choice of collector market outlet was affected by extension contact number, yield per hectare and price of the product positively affected, and factors access to credit, access to transport facility negatively affected. This was because, with access to transport and they have capital, they want to choose consumer market outlet giving a good price. The predicted probabilities of the choice collector market outlet are $69 \%$ [120-128].

The joint probability of choosing for all outlets was only $\mathbf{2 . 2 9 \%}$. It was unlikely for farmers to choose four outlets simultaneously. Since all four outlet choices were not profitable for farmers from the channel they choose the important outlets to maximize utility. However, the joint probability is not to choose all market outlet was $5.43 \%$. This implies that the household is less likely to fail without choosing one market outlet at a time by assuming the need for conducting institutional services and outlets that maximize the benefit of farmers.

\section{Summary, conclusions and recommendation}

Summary : The study was aimed at analyzing value chain of 'enset' at Mareka and Loma Woredas of Dawuro zone southern part of Ethiopia. The specific objective of the study includes identification and mapping the function of actors along the value chain, examine cost and share of benefits distribution along the value chain, analyzing factor affecting farmer participation and outlet choice of the producer. The data was generated both from primary and secondary sources. The primary data were collected from individual interviews using pre-tested semistructured interview schedules and checklists. Multistage sampling technique was employed to select Woredas, kebeles and Sample respondents by using Cochran (1963:75) sampling formula 152 farmers selected randomly and 57 traders and 66 consumers selected purposively, totally 275 respondents used for the study. 
To describe the characteristics of value chain actors' descriptive statistics like mean, standard deviation t-test $c h i^{2}$.test and percentage were used to test the dummy and continuous variables for the study. Data, which collected by interview schedules were coded, entered by editing and analyzed by using STATA version 13. Mapping of value chain analysis was done to describe the function of actors and to show the value chain activity of 'enset'.

Marketing chain and margin analysis were employed to realize the cost and benefit distribution of actors. Tobit model was used to interpret the standpoint of the study to look factors that affect farmer's participation. Determinants of market outlet choices were identified by using Multivariate Probit model. The 'enset' production subsector is increasingly becoming important in poverty reduction.

Based on the result obtained from survey data, $74.4 \%$ of the respondents participated in 'enset' product market and value addition and the reaming $25.6 \%$ of respondents are producing enset for home consumption. Only 0.31 quintal of 'enset' from average 1 quintal produced per week was supplied to the market. $56 \%$ of households were illiterate and the remaining educated from grade $1-8$. This indicates that, large percent of enset producers are illiterate.

From the total representative of 152-sample 'enset' producers handled during survey year, about 103 were male and 49 were female-headed households. The average age and family size of sampled respondents were 46.97 years and 6.3 respectively. Enset value chain analysis of the study area revealed that the main value chain actors were input suppliers, 'enset' producing farmers, local collectors, wholesalers, retailers, and consumers. Woreda agricultural and rural development office (OoARD) and the office of Trade and Industry is the main supporter of 'enset' value chain in the study area.

Producers produce the product and sell for all actors at the different market outlet. Collectors were engaged in purchasing enset product from the farm gate and local market and sell the product to town markets to wholesalers, retailers, and consumers. Retailers, purchase 'bulla' and kocho from producers at farm gate, local market, purchase from collectors at local market and wholesalers and sell the product to consumer and hotel owners. Wholesaler, purchasing the products from farmer and collector and again sells it to retailers, consumers and hotel owners at the urban market outlets.

The function given by supportive body answered by representative actors were, facilitating functions, awarenesscreating, credit, strategy facilitating, training support. AGP, SLM, Action Aid, Areca Agricultural Research Center (ARARC) Wolaita TEVET, Woreda agriculture office, Rural OMO microfinance were main actors involved in the production and marketing activity of enset products value chain.

Actors along enset value chain have weak marketing cooperation among them in the study area. This result indicates that limited know how on 'enset' value addition, information on price and weak bargaining power of farmers. Most of the traders who have been participating in 'kocho' and 'bulla' have no license. This shows that traders have more experience with traditional 'enset' marketing system along 'enset' value chain in the study area.

Generally, enset marketing system in the area was operated by underdeveloped and inefficient value chain system. The factors affecting the improvement of 'enset' value chain were found in all of the chains. which are lack of improved technology and disease resistance variety, less training given to value addition, less attention of extension service in relation to other cereal crops, limited access to the market, low price to the producer, limited transport facility, limited credit facility and low arrangement of market organization in relation to other product marketing.

The identified direct actors of the enset value chain are local collectors $(28.1 \%)$, wholesalers $(38.6 \%)$ and retailers $(33.1 \%)$ with the value being added before reaching the end user. They have kocho and bulla from the producer farmer at a lower price and they sell to the consumer at a higher price. The average price that sample respondents received for a quintal of 'kocho' is 200 Birr and 'bulla' is 500 Birr.

The result of the study shows that the traders operating expense for 'kocho' and bulla were $26 \%$ and $20 \%$ respectively from a total value chain expense. However, their profit margin is almost $74 \%$ and $80 \%$ of the total profit margin for 'kocho' and 'bulla' respectively. The result of the study shows that kocho trader $\mathrm{s}$ are simply buying from the farmer at the different outlet of product and selling to the consumer are earning $74 \%$ of the total profit margin. Therefore, farmers operating all work from plantation up to market with taking challenges and risks in production have only $26 \%$ of the profit margin.

The share of the profit margin of local collectors' wholesalers and retailers from kocho was $27 \%, 22 \%$, and $25.08 \%$ respectively. This shows that local collectors were benefited more than other actors in kocho value chain and retailers are benefited more than other actors in 'bulla' market chain.

The distribution of benefit along enset value-chain actors varies from marketing channel in which the product was distributed to each actor. The gross marketing margin of producer (GMMF) in channel I is $100 \%$. This result shows that producer directly sold kocho to consumers at a better price without the interruption of the intermediary. Wholesalers get the highest marketing margin at channel IV, III and VI $67 \%$, $63 \%$, and $40 \%$ respectively. The lowest share of gross margin registered for the farmer at channel VII accounts about 39\%. The retailers got highest gross marketing margin at channel II and V and lowest at marketing channel VII. GMMr is high on the channel I indicated that they purchase 'bulla' at an optimum price from producer directly and sold to a consumer for good price. This implies retailers not incur more marketing cost, but benefit more in channel II than other channels. 
The share of the profit margin of local collector's wholesalers and retailers were $25.32 \%, 22.15 \%$, and $26.58 \%$ respectively from the sales of one quintal of 'bulla'. The wholesalers got the highest marketing margin at channel IV, III, VI 67\%, $63 \%$ and $40 \%$ respectively and the lowest at marketing channel VII accounts about $39 \%$. The retailers got highest gross marketing margin at channel II and V and lowest at marketing channel VII. This implies that retailers of bulla in the study area are incurring less marketing cost and benefit more in these two channels than others.

Factors affecting farmer's participation and level of market participation were, positively associated by the education level of household, yield per hectare, consumer preference access to transport facility and price of product are statistically significant and family size distance to market and incidence to disease are negatively significant respectively.

The identified market outlet choices by producer were a wholesalers, collectors, retailers, and consumers. The multivariate probit models were applied to identify factors affecting market outlet choice of the producer. The choice of farmers to consumer outlet was significantly negatively affected by education level of the household.

The predicted probability to choose consumer outlet was $29 \%$. The choice of the farmer to wholesaler market outlet was influenced by extension frequency contact and price positively. The predicted probabilities of choosing wholesaler outlet were $44 \%$. From factors which affect retailers market outlet choice, distance to nearest market and output produced are significantly positively and packing animal owner and price negative to choose retailer market. The predicted probabilities of choosing collector market outlet is $69 \%$. From factors, which affect retailer's market outlet choices distance to nearest market and output produced were significantly positively and packing animal owner and price were negative to choice retailer market.

\section{Conclusion}

The lowest value chain activity development of 'enset' product generated limitation to output rewarding markets due to high transaction cost arising from transportation and the high opportunity cost of labor involved. Producers and consumers are spatially separated; most farmers are found in the rural areas; consumers and hotel owners market which gave good price are found at urban market outlets and which tend to reduce the participation of producer to market. Most of enset supply from producer to consumer through informal means in both rural and urban areas, because market infrastructure and marketing facility are not well developed. This reduces the participation of enset producer to market.

Similarly, limited market outlet, less market linkage, and poor market information are the major challenges in 'enset' value chain hindering the market. However, smallscale producers are unlike to exploit market opportunities in negotiating the price which resulted in less distribution of benefit to the producer along the value chain.
From the study result, the main value chain actors were input suppliers, enset producing farmers, local collectors, wholesalers, retailers, and consumers. Woreda agricultural and rural development office (WORD) and the Office of Trade and Industry is the main supporter of enset product value chain in the study area. The data of research shows that less accessibility to market information, less power for market penetration and less market arrangement make the farmers less price taker and trader in a better position to dominate the market price and govern the chain.

The study shows that traders operating expense from 'kocho' and bulla were $26 \%$ and $20 \%$ of a total value chain expenses, but their profit margin is almost $74 \%$ and $80 \%$ of the total profit margin for kocho and bulla respectively. The study results of demographic factors such as age, education level, sex, family size, socio-economic factors, land size, labor, and quantity of 'enset' produced, hectares of 'enset' crop owned, wild animals and population pressure. Institutional factors such as access to extension service, access to credit, access to market information and access to transport facility and distance to market, consumer preference and physiological factors, like incidence to disease, pest, are hypostasized influential factors to the participation and outlet choice of producer.

From the variables, factors affecting farmer's participation of enset product market were positively associated with the education level of the household, access to market information, yield per hectare, consumer preference and price of the product and negatively related with distance to market; family size and incidence of disease were identified by Tobit model.

The choice of farmers to consumer outlet was significantly affected negatively by education level of the household. From factors which influence wholesaler market were the age of household head, distance to market, extension frequency contact, access to transport facility and price were significant. The choice of the farmer to wholesaler market outlet was influenced by extension frequency contact and price positively. From factors which affect retailers market, outlet choice distance to nearest market and output produced are positively significant and packing animal owner and price positively to choice retailer market. The choice of collector market outlet was affected by extension contact number, yield per hectares and price of the product positively and factors access to credit, access to transport facility negatively affect.

Therefore, to promote value chain of 'enset' (Ensete ventricosoum): at Mareka and Loma Woreda of Dawuro zone intervention on factors affecting 'enset' value chain at study area increase household income food self-sufficiency, promote the likelihood and moreover by encouraging marketing requirements for the producers and traders.

\section{Recommendations}

Based on the finding enset should be intensified to satisfy the market demand and to give normal profit for all actors along 'enset' value chain. 
As a source of food and income for producers there is limitation of institutional support for the sector, such as access to credit, market information, and extension services. According to a wide range of difference between farmers was due to not using inputs like manure, the poor frequency of extension contact, less training given for product value addition and poor disease controlling system. Therefore, the focus of extension service has to be improved to increase farmer's access to market information and extension support through giving training and awareness creation from agricultural offices and research center.

The share of benefit distribution among 'enset' value-chain actors is different from producer to the retailers. The profit share of the producer is less than $26 \%$ of 'kocho' and $25.95 \%$ of 'bulla' which is less than traders. Therefore, putting in place and strengthening appropriate extension and marketing institution for giving timely and good market information for enset producer is so important and farther studies to be done by Action Aid, Areca research center and the policy issue by government for the sector of 'enset' marketing should be considered.

Marketing portals for the product are not arranged in observation to marketing actors. Therefore, the market segment for the product in relation to actor's participation should improve by Woreda Trade and Industry Office according to convenience to buyers and sellers massive contact to the produce.

Therefore, the farmers have to link production with marketing products based on market signals, consumer preferences or advising good quality and packing material to improving quality. Therefore, it is recommended to make efficient extension system on the produce improving the knowledge and skill of extension agents with production and marketing of 'enset'.

The 'enset' product 'bulla' directly traded in row form between producer and traders to consumers at Zonal, local and urban markets at a low price. While this shows that less knowledge of producers and trader to process and pack in powder form. Therefore, to capacitate bulla producers and traders on processing powder bulla and packaging technology training should be needed from agricultural organizations.

In case of production, households with the limited education distant market and with a large number of dependent age group and less extension frequency contact, limited participation in the market. Therefore, Actin Aid, SLM, Agriculture office and Trade and Industry Office have to create infrastructural and institutional development.

In addition, large numbers of farmers have responded the existence of disease incidence, pest, and wildlife attack. Thus the presence of crop disease in production year created yield reduction of the product according to this survey and reduced market participation of the producer. In order to avoid the reduction of production and increase market participation of the farmer, awareness creation for integrated disease and pest management to be done and crop protection services through availing chemicals for enset Melbug and bacterial welt or locale ('Woluwa') required preventing disease.

From the factors affecting enset value chain of study area: education level of households, access to market information, access to transport, price and consumer preference had positive implications are maintained and further encouraging work to be done. In another side, the factors, which show negative implication on enset, value chain that are - distance to market, incidence to disease and off-farm activities in relation which affect the production marketing and value chain activity, considers policy implication in enset value chain needs work from agriculture office and research center.

The joint probability of choosing for the outlet was only $2.29 \%$. It was unlikely for farmers to choose four outlets simultaneously. Since all four outlets choices were not profitable for farmers they choose the important outlets to maximize utility. However, the joint probability not to choose all market outlets was $5.43 \%$. This implies that the household less likely to fail without choosing one market outlet at a time by assuming the need for conducting institutional services to choose outlets that maximize the benefit of farmers.

Moreover, there has to be an institution that can provide true information required for producers timely. This makes the marketing system efficient for all actors participating in the value chain of 'enset'.

Therefore, as the study conducted shows zonal and woreda agricultural offices and respective offices, Areca research center, zonal and woreda cooperative and trade offices need to work improving the capacity of producers in order to encourage and improve their skill on choosing appropriate market outlet for their product and focus on identified constraints and opportunities to improve the value chain of enset at study area.

\section{References}

1. CSA (2012) Southern Nations, Nationalities, and Peoples' Region Wayback Machine.

2. Giorgis G, Gebre E, Bedane K, Kassa B (2001) Country Profile on Potato Production and Utilization: Ethiopia. Ethiopian Institute of Agricultural Research Holetta Agricultural Research Centre, National Potato Research Program.

3. Adimassu Z, Kessler A (2014) Factors affecting farmers' coping and adaptation strategies to perceived trends of declining rainfall and crop productivity in the central Rift valley of Ethiopia.

4. Tenaye A, Geta E (2008) Analysis of vulnerability and determinants of enset production in Wolaita, Southern Ethiopia. In International Symposium on Underutilized Plants for Food Security, Nutrition, Income and Sustainable Development 806: 663-668.

5. Negash A (2001) Diversity and conservation of enset (Enseteventricosum (Welw.)Cheeseman) and its relation to household food and livelihood security in southwestern Ethiopia.PhD thesis, Wageningen University and Research Centre. Link: https://bit.ly/3gfPujh

6. CSA (2011) Area and Production of Major Crops.Agricultural Sample Enumeration Survey part III. Addis Ababa, Ethiopio.

7. AWiersum TKF, BongersF (2010) Spatial and temporal variation in crop 
diversity in agroforestry home gardens of southern Ethiopia.Agrofor syst.78:309-322. JournalofEthnobiology and Ethnomedicine. 18to the School of Graduate Studies in Addis Ababa University in Partial. Link: https://bit.ly/3l3Zsb6

8. Abebe T (2013) Determinants of crop diversity and composition in Enset coffee agroforestry homegardens of Southern Ethiopia.Journal of Agriculture and Rural Development in the Tropics and Subtropics (JARTS). 114: 29-38. Link: https://bit.ly/34ksoWr

9. FAO (2010) Global Forest Resources Assessment 2010 Country Report Ethiopia. Food and Agriculture Organization (FAO), Rome, Italy. Link: https://bit.ly/3gjq4Bt

10. Temesgen M, Bizuayehu T, Marcello C, Mario E (2014) Indigenous knowledge, use and on-farm management of enset (Enseteventricosum(Welw.) Cheeseman) diversity in Wolaita, Hawassa University, School of Plant and Horticulture Science, Hawassa, Ethiopia. Link: https://bit.ly/3hiCSJt

11. Tsedeke K (2011) Agro-ecologic mapping of livestock system in smallholder crop-livestock mixed farming of Wolaita and Dawuro districts, Southern Ethiopia, Areka Agricultural Research Center, P.O. Box 79, Areka, Ethiopia. Link: https://bit.ly/31hZmVi

12. Lomba YL (2015) Production objectives, breeding practices and selection criteria of indigenous goat in Loma District, Southern Ethiopia. Global Journal of Animal Scientific Research 3.

13. Cochran WG (1963) Sampling Techniques. $2^{\text {nd }}$ Ed., New York: John Wiley and Sons, Inc. Link: https://bit.ly/3gmhrpv

14. UNIDO (United Nations Industrial Development Organization) (2009) The impact of Global Economic \& Financial Crises on the Ethiopian Dairy Industry.

15. Mendoza MS, Rosegrant MW (1995) Pricing conduct of spatially differentiated markets. PricesProducts and people: Analyzing agricultural markets in developing countries 343-360.

16. Negussie M (2011) Value chain analysis of sugarcane: the case of kaluWoreda south Wollo zone of Amhara national regional state, Ethiopia. A Thesis Submitted to the College of Agriculture and Environmental Science, School of Agricultural Economics and Agribusiness, School of Graduate Studies Haramaya University.

17. Sindi J (2008) Kenya domestic horticulture subsector: What drives commercialization decisions by rural households? Unpublished MSc. Dissertation. Michigan City, Michigan State University, USA. Link: https://bit.ly/2QfOVNv

18. Greene W (2003) Econometric Analysis. Fifth Edition. Prentice Hall, New Jersey. Link: https://bit.ly/32rpUTN

19. Velandia M, Rejesus RM, Knight TO, Sherrick BJ (2009) Factors affecting farmers' utilization of agricultural risk management tools: the case of crop insurance, forward contracting, and spreading sales. Journal of Agricultural and Applied Economics 41: 107-123. Link: https://bit.ly/3lcWn8X

20. Rao VR (2011) How Peer Influence Affects Attribute Preferences: A Bayesian Updating Mechanism" (with Vishal Narayan and Carolyne Saunders), Marketing Science 30. Link: https://bit.ly/2FEXOrf

21. Maddala GS (2000) Introduction to Econometrics (3 ${ }^{\text {rd }}$ edition). New Jersey: Prentice-Hall Inc.

22. Takele A (2010) Analysis of Rice Profitability and Marketing Chain: The case of Fogera Woreda, South Gondar Zone, Amhara National Regional State Ethiopia. Unpublished MSc. Thesis, HaramayaUniversity, Amhara, Ethiopia. Link: https://bit.ly/2Q97VM2

23. Musah AB (2013) Market Participation of Smallholder Farmers in the Uppe West Region of Ghana (Doctoral dissertation, University of Ghana). Link: https://bit.ly/3gl7RDo
24. Tegegn A (2013) Value Chain Analysis of Vegetable: The Case of Habro and Kombolcha Woredas in Oromia Region, Ethiopia. An MSc Thesis Presented to School of Graduate Studies of Haromaya University.

25. Chaka A, Kenea T, Gebresenbet G (2019) Analysis of the Supply Chain and Logistics Practices of Warqe Food Products in Ethiopia. International Journa on Food System Dynamics 7: 213-228. Link: https://bit.ly/2Qdv1Rz

26. Teshome M (2014) Population growth and cultivated land in rural Ethiopia: land use dynamics, access, farm size, and fragmentation. Resources and Environment 4: 148-161. Link: https://bit.ly/3I4AuZd

27. Abebeuma (2015) market performance of Enset product kocho and bulla: The case of dire enchini Woreda, Oromia regional, state, of Ethiopia. Link: https://bit.ly/2Ed5rd7

28. Chandio AA, Wagan SA, Sethar AA, Kalwar GY, Bhatti MA, et al. (2015) Analysis of Rice Profitability and Marketing Chain: A Case Study of District Sukkur Sindh Pakistan. Link: https://bit.ly/3gf9thV

29. Geda TW (2009) Globalization and NEO-liberalization: challenges and opportunities to enset crop-based agricultural \{communities and their farming system in Ethiopia (Doctoral dissertation, University of Alberta). Link: https://bit.ly/3l3W5Ru

30. GebreselassieS,SharpK(2008)Commercialisation of Smallholder Agriculture in Selected Tef-growing Areas of Ethiopia. Future Agricultures Consortium, A discussion paper, University of Sussex, Brighton, UK, Link: https://bit.ly/31ij1EN

31. Abebeuma (2015) Enset value chain analysis: the case of dire enchini Woreda, Oromia regional state, Ethiopia student department of rural development \& agricultural extension institute of co-operatives \& development studies Ambo University.

32. Nuri LT, Jema H (2019) Value Chain Analysis of Enset (Ensete ventricosum) in Hadiya Zone. Southern Ethiopia (Doctoral dissertation, Harmaya University).

33. Eshetu OM (2019) Determinants of credit constraints in Ethiopia (Master's thesis, UiT Norges arktiske universitet)

34. Muthini DN, (2015) An Assessment of Mango Farmers'choice Of Marketing Channels In Makueni, Kenya (Doctoral dissertation, University of Nairobi). Link: https://bit.ly/3aHqrEK

35. Kohlin CF, Mekonnen A, Yesuf M (2005) Are Agricultural Extension Packages What Ethiopian Farmers Want? A Stated Preference Analysis, WorkingPapers in Economics. Department of Economics, Goteborg University. choice of marketing channels: micro-level evidence. Ethiopian Economics Association,

36. Nwigwe C (2009) Socioeconomic factors affecting intensity of market participation among smallholder yam-based system farmers in Oyo North area of Nigeria. International Journal of Economic Perspectives 3: 131. Link: https://bit.ly/329Xai9

37. Yasbabu S (2015) Preventing and mitigating the effects of enset wilt in Ethiopia. Link: https://bit.ly/2YncHdk

38. Azerefegne $F$, Addis T, Alemu T, Lemawork S, Tadesse $E$, et al. (2009) An IPM guide for Enset root mealybug (Cataenococcusensete) in Enset production. Bioversity International, Uganda and France offices. Link: https://bit.ly/2YnGoLd

39. Bezuneh T (2012) Technological Challenges of Sustainable Enset Farming System: For Enhancing the Production of food/Fiber and Industrial Outputs. Enset research and development experiences in Ethiopia, Proceedings of Enset National Workshop 19-20.

40. Hellin J, Griffith A, Albu M (2005) Mapping the market: market-literacy for agricultural research and policy to tackle rural poverty in Africa.In Beyond agriculture-making markets work for the poor. Proceedings of an international seminar. Link: https://bit.ly/3j4dvLQ

Citation: Haile A, Megerssa B, Negash R (2020) Enset (Ensete Ventricosoum) Value Chain in Dawuro Zone, Southern Ethiopia. Int J Agric Sc Food Technol 6(2): 126150. DOI: https://dx.doi.org/10.17352/2455-815X.000065 
41. Cormick D, Schmitz H (2002) Manual for value chain research on home workers in the Garment Industry, IDS, Brighton. Link: https://bit.ly/327Po8m

42. Anandajayasekeram $P$, Gebremedhin $B(2010)$ Integrating innovation systems perspective and value chain analysis into agricultural R4D: issues and challenges. ILRI (International Livestock Research Institute), Nairobi, Kenya. Link: https://bit.ly/34j49b0

43. Vorley B, Lundy M, MacGregor J (2009) Business models that are inclusive of small farmers. Agro-industries for Development, Wallingford, UK: CABI for FAO and UNIDO. 186-222.

44. Degu G (2012) Experiences on Enset Technology Dissemination and Value Chain Analysis.In: Mohammed Y. and Tariku H. (eds.). Enset research and Development Experience in Ethiopia. Proceeding from Enset National Workshop held in Wolkite, Ethiopia 19-20.

45. Getinet H (2009) The impact of global economic and financial crises on the Ethiopian dairy industry.

46. Martin G, Boualay O, Julio B (2007) North Houaphanh bamboo value chain analysis. Netherland. Link: https://bit.ly/3hgXm5z

47. Holloway G, Ehui S (2002) Expanding market participation among smallholder livestock producers: A collection of studies employing Gibbs sampling and data from the Ethiopian highlands. Socio-economic and Policy Research Working Paper 48.ILRI, Nairobi, Kenya. IAR, Addis Ababa, Ethiopia 85. Link: https://bit.ly/2QfgpkC

48. Enibe DO, Chidebelu SAND, Onwubuya EA, Agbo C, Mbah AA (2008) Policy Issues in the Structure, Conduct and performance of Banana Market in Anambra State, Nigeria. Journal of Agricultural Extension 12: 32-40. Link: https://bit.ly/2QdcAwq

49. Alene AD, Manyong VM, Omanya G, Mignouna HD, Bokanga $M$, et al (2008) Smallholder market participation under transactions costs: Maize supply and fertilizer demand in Kenya. Food Policy 33: 318-328. Link: https://bit.ly/3aHstET

50. Tadesse A (2011) Market chain analysis of fruits for Gomma woreda, Jimma zone, Oromia National Regional State (Doctoral dissertation, Haramaya University). Link: https://bit.ly/31eQfos

51. Zeberga A, Yemataw Z, Sinebo W, Ambachew D (2014) On farm cultivar diversity of enset (Ensete ventricosum w.)in southern ethiopia. Link: https://bit.ly/2YnPYOD

52. Bwalya R, Mugisha J, Hyuha T (2013) Transaction costs and smallholder household access to maize markets in Zambia. Journal of Development and Agricultural Economics 5: 328-336. Link: https://bit.ly/2E42MT7

53. Cunguara B, Mudema J, Mather D, Tschirley D (2012) Changes in smallholder cropping and input use in Central and Northern Mozambique, 2008/2011. Flash: Research results from the Directorate of Economics, Ministry of Agriculture 60. Link: https://bit.ly/2FCh25I

54. Osmani AG, Hossain E (2015) Market participation decision of smallholder farmers and its determinants in Bangladesh. Ekonomika Poljoprivrede 62: 163-179. Link: https://bit.ly/2QfCgsl

55. Nuri L (2019) Determinants of Market Participation among Kocho Producers in Hadiya Zone, Southern Region, Ethiopia. Journal of Marketing and Consumer Research 21.

56. Weisbrod G (2008) Models to predict the economic development impact of transportation projects: historical experience and new applications. The Annals of Regional Science 42: 519-543. Link: https://bit.ly/31dUaSz

57. Gebre H, Bekele A (2015) Analysis of Potato Value Chain in Hadiya Zone of Ethiopia (Doctoral dissertation).

58. Emana B, Gebremedhin H (2007) Constraints and opportunities of horticulture production and marketing in eastern Ethiopia. DCG. report. Link: https://bit.ly/3j006EH
59. Sigei G, Bett H, Kibet L (2014) Determinants of market participation among small-scale pineapple farmers in Kericho County, Kenya. Link: https://bit.ly/2YjrMMM

60. Barrett CB (2008) Smallholder market participation: Concepts and evidence from eastern and southern Africa. Food Policy 33: 299-317. Link: https://bit.ly/3aJ2cWE

61. Barrett CB, Swallow BM (2006) Fractal Poverty Traps. World Development 34: 1-15.

62. Emana B (2010) Market assessment and value chain analysis in BenishangulGumuz Regional State, Ethiopia.SID-Consult-Support Integrated Development, Addis Ababa, Ethiopia. Link: https://bit.ly/2EgwF2m

63. Bongiwe G, Masuku B (2012) Factors affecting the choice of marketing channel by vegetable farmers in Swaziland. Canadian Center of Science and Education. Sustainable Agriculture Research 2: 123. Link: https://bit.ly/2YoXubM

64. Cadot O, Dutoit L, Olarreaga M (2006) How Costly Is It for Poor Farmers to Lift Themselves Out of Subsistence? World Bank Policy Research Working Paper 3881. Link: https://bit.ly/32aiROV

65. Cramer GL, Jensen W, Southgate DD (1997) Agricultural Economics and Agribusiness, 7th Edition.John Wiley and Sons, Inc. USA 315-340.

66. DARD (2015) Dawuro zone agricultural office bulg season 2015. Report of extension on root and tuber crop production.

67. Dereje A (1985) Studies on the bacterial wilt of enset (Enset ventricosum) and prospect for its control. Ethiopian Journal of Agricultural science 7: 1-14. Link: https://bit.ly/31gDSby

68. Beyera D (2004) Impact of community managed irrigation on farm production efficiency and household income. The case of Weliso and Wenchi districts of Oromiya Regional State. M.Sc. Thesis Presented to the School of Graduate Studies, Haramaya University. 46.

69. Diao X, Dorosh P (2007) Demand constraints on agricultural growth in East and Southern Africa: A general equilibrium analysis. Development Policy Review 25: 275-292. Link: https://bit.ly/3aQRnlp

70. Martey E, Al-Hassan RM, Kuwornu JKM (2012) Commercialization of smallholder agriculture in Ghana: A Tobit regression analysis. Link: https://bit.ly/2E5nli5

71. Fakoya O, Agbonlahor M, Dipeolu A (2007) Attitude of women farmers towards sustainable land management practices in South-Western Nigeria. World Journal of Agricultural Sciences, 3(4): 536-542. Link: https://bit.ly/34lhXSk

72. Gereffi G, Humphrey J, Sturgeon T (2005) The governance of global value chains. Review of international political economy 12: 78-104. Link: https://bit.ly/34jJfsp

73. Gessesse A (2009) Analysis of fruit and vegetable market chains in Alamata, Southern Zone of Tigray: the case of onion, tomato and papaya (Doctoral dissertation, International Livestock Research Institute). Link: https://bit.ly/2EkeWqK

74. Beshargo G (2002) Cattle Marketing in Western Shewa. M.Sc Thesis Presented to graduate School of Graduate Studies of Alemaya University, Ethiopia.

75. Girma M, Abebaw D (2012) Patterns and Determinants of Livestock Farmers' Choice of Marketing Channels: Micro-level Evidence. EEA/EEPRI working paper. Addis Ababa. Link: https://bit.ly/327FuUe

76. Giroh DY, Umar HY, Yakub W (2010) Structure, Conduct and Performance of farm gate Marketing of Natural Rubber in Edo and Delta States, Nigeria.African Journal of Agricultural Research 5: 1780-1783. Link: https://bit.ly/31hJ8M2

77. Goetz SJ (1992) A selectivity model of household food marketing behavior in sub-Saharan Africa. American Journal of Agricultural Economics 74: 444-452. Link: https://bit.ly/31iG9Dg

Citation: Haile A, Megerssa B, Negash R (2020) Enset (Ensete Ventricosoum) Value Chain in Dawuro Zone, Southern Ethiopia. Int J Agric Sc Food Technol 6(2): 126150. DOI: https://dx.doi.org/10.17352/2455-815X.000065 
78. Goshu F (2015) Sectoral Analysis of the Impact of Foreign Aid on Economic Growth in Ethiopia: Time Series Analysis of Agriculture, Education and Health Sectors. diplom. de. Link: https://bit.ly/2Qf9oAi

79. Hagos F, Haileselassie A, Getnet K, Gebregziabher G, Bogale A, et al. (2019) Marketing patterns of rainfed and irrigated systems: Do they differ?

80. Hawkes C, Ruel MT (2011) Value Chains for Nutrition. 2020 Conference Paper 4, prepared for the IFPRI 2020 International Conference "Leveraging Agriculture for Improving Nutrition and Health", February 10-12, New Delhi, India.

81. Heltberg R, Tarp F (2002) Agricultural Supply Response and Poverty in Mozambique. Food Policy 27: 103-124. Link: https://bit.ly/34gQlhr

82. Hobbs JE, Cooney A, Fulton M (2000) Value chains in the agri-food sector What arethey? How do they work? Are they for me? Department of Agricultura Economics, Universityof Saskatchewan. Canada. 31.

83. Holloway G, Barrett CB, Ehui S (2005) The Double-Hurdle Model in the Presence of Fixed Costs.Journal of International Agricultural Trade and Development 1 : $17-28$.

84. Humphrey J (2003) 'Globalisation and Supply Chain Networks: The Auto Industry in Brazil and India', Global Networks 3: 121-141. Link: https://bit.ly/2QePI4Z

85. Humphrey J, Schmitz H (2000) 'Governance and Upgrading: Linking Industrial Cluster and Global Value Chain Research', IDS Working Paper,120, Brighton: Institute of Development Studies, University of Sussex. Link: https://bit.ly/32gyWmc

86. IFAD (2003) Promoting Market Access for the Rural Poor in Order to Achieve the Millennium Development Goals. Discussion Paper. Rome. Link: https://bit.ly/3ghzeOP

87. Hlongwane L, Ledwabc S, Beleta A (2012) Analysing the factor affecting the market participation of maize farmer; acase study small scale farmers in greater Giyani Local Municipality of Mopani District Limpopo province.

88. Snowden AR (1970) Multivariate probit analysis. Biometrics 26: 535-546. Link: https://bit.ly/2Qcei15

89. Jagwe J, Machethe C, Ouma E (2010) Transaction costs and smallholder farmers' participation in banana markets in the Great Lakes Region of Burundi. Rwanda and the Democratic Republic of Congo. Afr J Agric Res 6: 1-16. Link: https://bit.ly/2YntIUD

90. Jeffrey R, Alwang ME, Taylor DB (2009) Effects of Access to Information on Farmer's Market Channel Choice: The Case of Potato in Tiraque Subwatershed Cochabamba, Link: https://bit.ly/32f8MAb

91. Kabeto AJ (2014) An analysis of factors influencing participation of smallholder farmers in red bean marketing in Halaba special district, Ethiopia (Doctoral dissertation, University of Nairobi). Link: https://bit.ly/31hm3sN

92. Kaplinsky R (2002) Gaining from Global Value Chains: The Search for the N thRent. In G. Gereffi (ed.), who Gets Ahead in the Global Economy? Industrial Upgrading, Theory and Practice, New York: Johns Hopkins Press

93. Kaplinsky R, Morris M (2000) A handbook for value chain research, IDRC Ottawa, Canada. Link: https://bit.ly/2EgsHXw

94. Key N, Sadoulet E, De Janvry A (2000) Transactions costs and agricultural household supply response. American Journal of Agricultural Economics 82 245-259. Link: https://bit.ly/3aOhc5x

95. Khan MA, Singh G (1997) Energy inputs and potential for agricultura production in Western Pakistan. Agricultural Systems 54: 341-356. Link: https://bit.ly/3aMn8fe

96. Mali F, IIRR (2006) Chain empowerment: Supporting African farmers to develop market. Royal Tropical Institute, Amsterdam; Faida Market Link, Arusha; and International Institute of Rural Reconstruction, Nairobi. Link: https://bit.ly/3hkOdsz
97. Kizito A (2008) Famine early warning systems network (FEWS NET) market guidance No.2. Structure-Conduct-Performance and food security.

98. Knorringa P, Pegler L (2006) Globalisation, firm upgrading and impacts on labour. Tijdschriftvooreconomische en socialegeografie 97: 470-479. Link: https://bit.ly/2EkckJs

99. Koenig T, Blatt J, Brake K, Kloss K, Nilges T, et al. (2008) Market-driven development and poverty reduction: a value chain analysis of fresh vegetables in Kenya and Tanzania, Berlin. Link: https://bit.ly/34lduiA

100. Kohl RL, Uhl JN (2002) Marketing of Agricultural Product, $9^{\text {th }}$ Edition, PrenticeHall of India PLC, New Delhi.

101. Philip K, Armstrong G (2010) Principles of marketing.pearson education. Link: https://bit.ly/3j4KvUz

102. Kuma, B., Getnet, K., Baker, D. and Kassa, B., 2011. Determinants of participation decisions and level of participation in farm level milk value addition: The case of smallholder dairy farmers in Ethiopia. Ethiop.J. Appl. Sci. Technol, 2(2), pp.19-30. Link: https://bit.ly/3giZGaE

103. Girma M, Abebaw D (2012) Patterns and determinants of livestock farmers choice of marketing channels: micro-level evidence. Ethiopian Economics Association, Addis Ababa, Ethiopia. 55.

104. Martey E, Al-Hassan RM, Kuwornu JK (2012) Commercialization of smallholder agriculture in Ghana: A Tobit regression analysis. African Journal of Agricultural Research 7: 2131-2141. Link: https://bit.ly/2YjHxDw

105. Mathewos A (2008) Ethnobotany of Spices, Condiments and Medicinal Plants in Loma and Gena Bosa Woredas of Dawro Zone, Southern Ethiopia. A Thesis Submitted.

106. Knight (European economic and social committee, Trade unions United Kingdom), The tole of social partners in the transition of young people from education from the labor market, 14 october, 2013 Brussels.

107. Mekbib Y, Deressa T (2019) Exploration and collection of root and tube crops in East Wollega and Ilu Ababora zones: Rescuing declining genetic resources.

108. Yirmaga MT (2012) Improving the Indigenous Processing of Kocho, an Ethiopian Traditional Fermented Food Department of Food Science and Post Harvest Technology, Institute of Technology, Haramaya University, Ethiopia. Link: https://bit.ly/3gojg5G

109. Yami M (2012) Dairy value chain actors and their roles and linkages in Arsi Highlands, Ethiopia Kulumsa Agricultural Research Centre EIAR Africa-RISING Quick Feedroject Inception Workshop, Addis Ababa. Link: https://bit.ly/3I5SXEM

110. Mogaji TS, Awolala DO, Olorunisola PF (2012) Marketing Performance and Efficiency of Evaporative-preservation Cooling System for Fresh Tomato Marketing in Ondo State, Nigeria.Afrcan Journal of Agricultural Research 8 : 468-474

111. Nations S (2005) Nationalities, and Peoples Region (SNNPR LIVELIHOOD PROFILE), Regional Overview. FEWSNET, USAID, Disaster prevention and preparedness commission (DPPC), the government of Ethiopia.

112. Olango TM, Tesfaye B, Catellani M, Pè ME (2014) Indigenous knowledge use and on-farm management of enset (Ensete ventricosum (Welw.) Cheesman) diversity in Wolaita, Southern Ethiopia. Journal of Ethnobiology and Ethnomedicine 10: 41. Link: https://bit.ly/2YI572C

113. Olukosi JO, Isitor SU (1990) An Introduction to agricultural marketing and price, principle and application. Living books series GU publications, Abuja, 115.

114. Olwande J, Mathenge M (2012) Market Participation among Poor Rura Households in Kenya Market Participation among Poor Rural Households in Kenya.Int.J.Agric.Econ., pp.18-24. Link: https://bit.ly/2E4b0L2

Citation: Haile A, Megerssa B, Negash R (2020) Enset (Ensete Ventricosoum) Value Chain in Dawuro Zone, Southern Ethiopia. Int J Agric Sc Food Technol 6(2): 126150. DOI: https://dx.doi.org/10.17352/2455-815X.000065 
115. Omiti JM, Otieno DJ, Nyanamba TO, McCullough E(2009) Factors influencing the intensity of market participation by smallholder farmers: A case study of rural and peri-urban areas of Kenya. African Journal of Agricultural and Resource Economics 3: 57-82. Link: https://bit.ly/2CMW0jP

116. Porter ME (1985) Competitive advantage: creating and sustaining superio performance (New York: the free press). Link: https://bit.ly/3goighW

117. Randela R, Alemu ZG, Groenewald JA (2008) Factors enhancing market participation by small-scale cotton farmers. Agrekon 47: 451-469. Link: https://bit.ly/3hkPKic

118. Mussema R (2006) Analysis of red pepper marketing: The case of Alaba and Siltie in SNNPRS of Ethiopia. M.Sc thesis presented to the School of Graduate Studies, Haramaya University 105. Link: https://bit.ly/2Qgk6Xa

119. Scarborough V, Kydd J (1992) Economic Analysis of Agricultural Markets A Manual of Marketing Series 5, Chatham, UK: Natural Resource Institute: 172. Link: https://bit.ly/3iY1SpS

120. Scott GJ (1995) Prices, Products and People: Analyzing Agricultural Markets in Developing Countries. Lynne Reinner Publishers, Boulder, London. 498. Link: https://bit.ly/2FNnMhv

121. Shank R, Chernet E (1996) Enset crop assessment: A Linear Model for Predicting Enset Yield and Assessment of Kocho Production. Addis Ababa: UN Emergencies Unit for Ethiopia and World Food Program.

122. Shigeta M (1990) Folk In-Situ Conservation of Ensete [Ensete ventricosum
(Welw.) EE Cheesman]: Toward the Interpretation of Indigenous Agricultural Science of the Ari, Sowthwestern Ethiopia. Link: https://bit.ly/3ghMFOD

123. Tefera T (2014) Analysis of Chickpea Value Chain and Determinants of Market Options Choice in Selected Districts of Southern Ethiopia. Journal of Agricultural Science 6. Link: https://bit.ly/34kuHZJ

124. Tura EG (2019) Determinants of Market Participation and Intensity of Marketed Surplus of Teff Producers in Bacho and Dawo Districts of Oromia State, Ethiopia. Agricultural Economics, Forthcoming.

125. Vermeulen S, Woodhill J, Proctor FJ, Delnoye R (2008) Opportunities for small-scale producers inclusion in dynamic markets in developing countries and transition economies: A synthesis of findings from eight country level chain-wide learning workshops. London, IIED, London. Link: https://bit. ly/3I5IDO7

126. Visser P, Steen M, Greiling J, Hayesso T, Neefjes R, Greijn H (2012) ProPoor Value Chain Development: Private Sector-Led Innovative Practices in Ethiopia. Addis Ababa: SNV Ethiopia. Link: https://bit.ly/2FGSaK9

127. World Bank Group (2013) Doing Business 2014: understanding regulations for small and medium-size enterprises. World Bank Publications 11. Link: https://bit.ly/2EbjPCw

128. ZamasiyaB,MangoN,NyikahadzoiK,SizibaS(2014)Determinants of soybean market participation by smallholder farmers in Zimbabwe. J Dev Agric Econ 6: 49-58. Link: https://bit.ly/3j1EszS

\author{
Discover a bigger Impact and Visibility of your article publication with \\ Peertechz Publications

\section{Highlights} \\ * Signatory publisher of ORCID \\ * Signatory Publisher of DORA (San Francisco Declaration on Research Assessment) \\ * Articles archived in worlds' renowned service providers such as Portico, CNKI, AGRIS, \\ TDNet, Base (Bielefeld University Library), CrossRef, Scilit, J-Gate etc. \\ * Journals indexed in ICMJE, SHERPA/ROMEO, Google Scholar etc. \\ - OAI-PMH (Open Archives Initiative Protocol for Metadata Harvesting) \\ * Dedicated Editorial Board for every journal \\ * Accurate and rapid peer-review process \\ * Increased citations of published articles through promotions \\ * Reduced timeline for article publication \\ Submit your articles and experience a new surge in publication services \\ (https://www.peertechz.com/submission).
}

Peertechz journals wishes everlasting success in your every endeavours.

Copyright: @ 2020 Haile A, et al. This is an open-access article distributed under the terms of the Creative Commons Attribution License, which permits unrestricted use distribution, and reproduction in any medium, provided the original author and source are credited. 